\title{
Thermoelectric Materials: a Brief Historic Survey from Metal Junctions and Inorganic Semiconductors to Organic Polymers
}

Prospero J. Taroni, ${ }^{[\mathrm{a}, \mathrm{d})}$ Itziar Hoces, ${ }^{[\mathrm{b}]}$ Natalie Stingelin, ${ }^{[\mathrm{a}]}$ Martin Heeney, ${ }^{*}[\mathrm{c}]$ and Emiliano Bilotti ${ }^{*}[\mathrm{~d}]$

Dadicated to the memory of Prof. Michael Bendikov and his many contributions to the field of organic electronics.

${ }^{a)}$ Dept. of Materials and Centre for Plastic Electronics, Imperial College London, London SW7 2AZ, $U K$

b) European Thermodynamics Ltd., 8 Priory Business Park, Wistow Road, Kibworth, Leiscestershire, LE8 ORX, UK

${ }^{c)}$ Department of Chemistry and Centre for Plastic Electronics, Imperial College London, London, SW7 2AZ, UK-m.heeney@imperial.ac.uk

${ }^{d)}$ School of Engineering and Material Sciences, Queen Mary University of London, Mile End Road, E14NS, London, UK-e.bilotti@qmul.ac.uk

\begin{abstract}
The use of thermoelectric technology is attractive in many potential applications, such as energy scavenging from waste heat. The basic principles for harvesting electricity from a temperature gradient were first discovered around 180 years ago, but the contemporary technology utilizing inorganic semiconductors was only developed since the early 1950s. The widespread use of this platform has so far been limited by a combination of relatively low efficiency in energy conversion or by issues related to the utilisation of rare, expensive and/or toxic elements that can be difficult to process. Recently much interest has been focused on the use of organic materials in thermoelectric devices, prompted by the possibility of developing large-area, low-cost devices. Considerable research in the last 20 years has been focused on understanding and improving organic thermoelectric properties, with remarkable progress recently published for compounds such as PEDOT and others. Here we provide an overview into thermoelectricity, from the initial discoveries made by Johann Seebeck to modern practical applications including the current trends in organic thermoelectric research.
\end{abstract}

Keywords: molecular electronics, nanostructure, polymers, semiconductors, thermoelectricity 


\section{Introduction: A Perspective on the History of Thermoelectricity}

The history of thermoelectricity started with the German-Estonian physicist Thomas Johann Seebeck (1770-1831). He noticed that a magnetized needle was deflected when suspended near a circuit formed between two metals exposed to a temperature difference. His discovery was first announced at the Berlin Academy of Sciences and published in 1822 as a magnetic effect. ${ }^{[1,2]}$ The concept was subsequently investigated by Hans Christian Ørsted who gave the correct physical explanation, that the needle was moved by a magnetic field resulting from an electric current generated in the wires, caused by the previously unknown thermal effect. ${ }^{[3]}$ Ørsted collaborated with Joseph Fourier in the construction of the first thermoelectric power generator made of bismuth and antimony thermocouples (1823), however the best known early application of the Seebeck effect was made by Georg Simon Ohm in 1826. He investigated the relationship between a potential applied across a conductor and the resultant electric current using a thermocouple to generate the voltage. ${ }^{[1,4]}$ Other contributions to the field were made by Jean Charles Peltier in 1834 (Peltier effect, related to the presence of heating or cooling at an electrified junction of two different conductors) ${ }^{[5,6]}$ and Sir William Thomson, also known as Lord Kelvin in 1851 (Thomson effect, describing the heating or cooling of a currentcarrying conductor with a temperature gradient). ${ }^{[5,7]}$

A large variety of thermoelectric generators (TEG) have since been designed, with highlights to an early model by M. Clamond (1869). He produced electric lights by means of his new thermoelectric battery made of iron junctions combined with antimony alloyed with zinc. This design was used to generate light at certain factories in Paris since 1875 and a new smaller model, although with the same power output was exhibited in 1879 alongside various electric lighting systems at the Royal Albert Hall in London. ${ }^{[8]}$ There were many other generators developed in the following years but the first commercially available TEG in the United Kingdom was the gas powered Thermattaix in 1925 for charging batteries used by radio devices. ${ }^{[9]}$ All these early systems used metal junctions and due to the low conversion efficiency, the thermopiles were large bulky devices.

In the 1930's significant advances were made by Abram Fedorivich Ioffe at the Physical-Technical Institute in St. Petersburg on the use of $p$ - and $n$-type $\mathrm{PbS}$ semiconductor for thermoelectric applications. His dedication to the topic culminated in 1949 with the development of a comprehensive theory of thermoelectric energy conversion by semiconductors, published by the USSR Academy of Sciences in 1950 as a classified edition, but subsequently declassified and translated into English and Japanese. ${ }^{[10]}$ His theory is well established to date, referred in almost all recent scientific papers on the topic as the "thermoelectric figure of merit", $Z T=\alpha^{2} \sigma T / \kappa$, where $\alpha$ is the thermopower or Seebeck 
coefficient, $\sigma$ is the electrical conductivity, $T$ is the absolute temperature and $\kappa$ is the thermal conductivity. As well as this important theoretical contribution, it is also relevant to mention Ioffe's numerous practical achievements including a ring-shaped TEG used in association with a paraffin lamp to power radio devices, and also the manufacture and testing of the first thermoelectric refrigerator in 1950, with improvements in subsequent years using other semiconductors ${ }^{[10]}$. Ioffe made further advance in this field throughout the 1950's developing different low temperature materials such as $\mathrm{PbSe}-\mathrm{PbTe}$ and $\mathrm{Bi}_{2} \mathrm{Te}_{3}-\mathrm{Sb}_{2} \mathrm{Te}_{3}$, as well as others. ${ }^{[11]}$ His new devices still had low efficiency but with the advantage of miniaturisation compared to metal junctions. The benefits were not sufficient however for large-scale commercialisation and electric power production due to the high price, toxicity and scarcity of the materials utilised, although these problems were overlooked for military applications. Bismuth telluride was used for producing extremely low temperatures, which are needed for the operation of sensors in thermal vision systems as well as for technologies such as heat seeking missiles. ${ }^{[12]}$

Another significant development in the thermoelectric field came in the early 1960's with the use of high temperature SiGe semiconductor materials for radioisotope thermoelectric generators (RTG), able to convert heat from nuclear fissile materials into electricity. ${ }^{[13,14]}$ These devices required different fuels such as ${ }^{144} \mathrm{Ce},{ }^{137} \mathrm{Ce},{ }^{90} \mathrm{Sr},{ }^{238} \mathrm{Pu}$ or ${ }^{242} \mathrm{Cm}$ isotopes, and a series of RTG based on ${ }^{90} \mathrm{Sr}$ had widespread use in the former USSR. ${ }^{[15]}$ Over 1000 installations were manufactured to power lighthouses and radio navigation beacons along the Arctic coast of Russia from the late 1970's until the early 1990's. These devices had a half-life of 29.1 years and until recently some of them were still in the process of decommissioning through a joint project between Norway and Russia, with alarming reports of significant risks to public health due to unguarded facilities. ${ }^{[16]}$ Another application for this platform was not only exploited by the USSR but also the USA, with NASA using the technology since the early 1960's for long-life isotope power generators in satellites, deep space probes, lunar or planetary landers. It has been used aboard of Nimbus, Transit, Pioneers, Voyagers, Galileo, Cassini and many other spacecraft including the two Viking landers as well as scientific instruments used by the Apollo missions. ${ }^{[17]}$ Most recently, the Curiosity Rover sent for exploration of the surface of the planet Mars was also powered by RTG (Figure 1). ${ }^{[18]}$ 


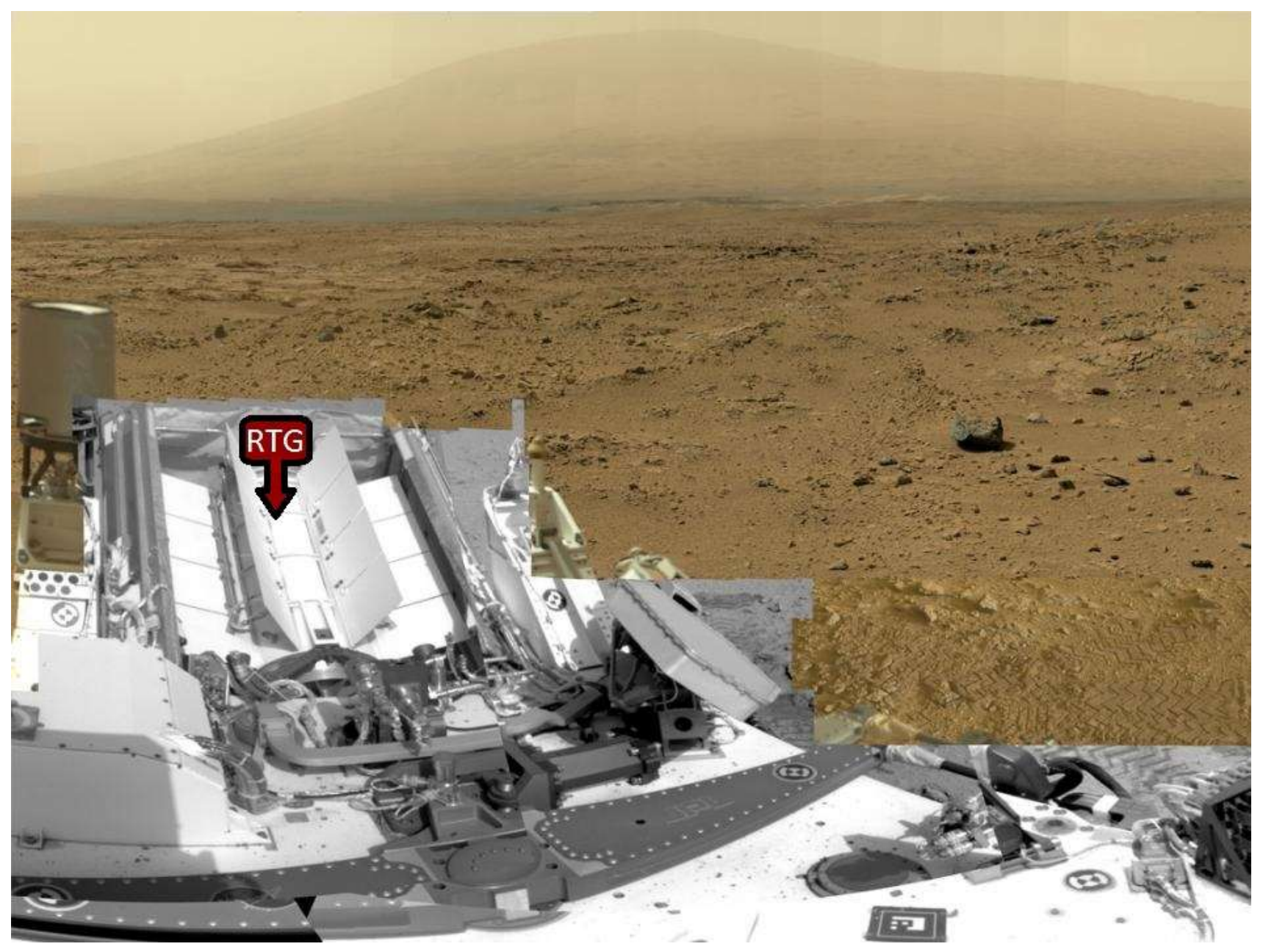

Figure 1: Billion-Pixel view from Curiosity at Rocknest, raw colour, showing the RTG at the rear of the Mars rover, taken between October 5 and November 16, 2012. Credits: NASA/JPL-Caltech/MSSS. ${ }^{[19]}$

Back to Earth, the possibility of mass producing TEG has been substantiated by advances in the field related to innovative inorganic and organic materials, some of them forecasted theoretically before being achieved experimentally. In 1993, Hicks and Dresselhaus predicted that reduced physical dimensionality of TE materials (quantum confinement) may lead to enhanced properties. ${ }^{[20,21]}$ Their predictions were confirmed in a number of experimental investigations and the idea is still in vogue to date. ${ }^{[22-26]}$ The ideal TE material is required to resembles a phonon-glass electron-crystal, meaning it should have phonon mean free paths as short as possible to have a low thermal conductivity, and at the same time electron mean free paths as long as possible to enhance electrical conductivity. ${ }^{[27]}$ Many inorganic materials have been investigated as candidates including skutterudites, clathrates, half heuslers, oxides, zintl, chalcogenides and porous silicon. ${ }^{[5,28-36]}$ Although some significant improvements have been achieved, the $Z T$ values remain stubbornly low, translating into limited efficiency of the devices.

The renewed interest in the technology during the last two decades was not only fuelled by scientific discoveries, but also by interest in reducing fossil fuel consumption as well as environmental concerns 
about refrigerant gas (CFCs). Thermoelectric devices offer potential for cooling without the use of any refrigerant gas, as well as the harvesting of wasted heat. The technology has already been prototyped in hybrid cars to reduce fuel use. Roughly $40 \%$ of the energy consumption of a vehicle is lost in the form of heat through the exhaust, ${ }^{[37]}$ so the opportunity for TE devices is large. Compared to other conventional technologies, heat is an untapped source of energy that is in most cases wasted to the environment. According to the Lawrence Livermore National Laboratory, an estimated $61 \%$ of the energy consumed in the USA in 2012 (95.1 Quads) was rejected as heat (58.1 Quads). ${ }^{[38]}$ If thermoelectric technology could be made cheaper with the use of polymers and related composites, the efficiency of the operating device itself could become less relevant when confronted with such large values of wasted energy. In this article we summarise some of the polymer compounds investigated to date for thermoelectric applications, as well as their composites with materials such as carbon nanotubes, graphene and others.

Before embarking on this voyage, it is necessary to detect other areas where modern TE technology has found its most useful applications, so that a sense of direction can be given in the course of this study. Commercialisation of inorganic TEG is still limited to some specialised niches, mainly due to the marginal improvement in material efficiency since discovery of $\mathrm{Bi}_{2} \mathrm{Te}_{3}$, as well as environmental and cost issues involved with the process. These problems have unfortunately obscured desirable advantages of this technology such as compactness of the device, silent operation during energy conversion, and reliability with virtually no maintenance required. Recent applications include mass produced miniature thermoelectric modules to maintain constant temperatures in the operation of laser diodes. ${ }^{[39]}$ Climate control seats have been fabricated by Gentherm Corporation and installed in hundreds of thousands of vehicles each year ${ }^{[40]}$. An interesting application is a cooking pot that generates power for charging mobile devices in off-grid locations. ${ }^{[41]}$ Microthermoelectric generators have high potential in many low-powered devices in many low power devices ${ }^{[42]}$ such as wrist watches ${ }^{[43]}$, portable beverage coolers ${ }^{[44]}$ amongst others. Promising areas for future expansion involve industrial waste heat recovery ${ }^{[12]}$, as well as integrated solar thermoelectric generators ${ }^{[45,46]}$ and micro Peltier coolers to recycle the undesirable heat produced by Si-chips in computers ${ }^{[47]}$. This is not an exhaustive list and the possibilities for applications are continuously widened by new developments in the field. Last year alone several inorganic as well as polymer based organic thermoelectric materials and devices have already been patented ${ }^{[48,49]}$, including large corporations such as Fujifilm (organic TE materials) ${ }^{[50]}$ and Sony (organic TE device), ${ }^{[51]}$ which is a reflection of the continued expansion of this field. 


\section{SOME BASIC CONSIDERATIONS}

The thermoelectric effect relates to the interaction of heat and electricity in a material. ${ }^{[52]}$ When used as a power generator (Figure $2 \mathrm{a}$ ), the charge carriers (electrons in the $n$-type segment and holes in the p-type segment) diffuse along a temperature gradient, producing an electrical current through the Seebeck effect. When used as a heat pump (Figure 2b), an electrical current is run across the two thermoelectric junctions with charge carriers absorbing heat at one junction and dissipating it at the other, based on the Peltier effect. A large variety of theoretical and experimental studies have investigated the principles governing the thermoelectric properties of different materials, but the knowledge is still quite fragmented. The efficiency is related to the figure of merit, ZT, which, as previously explained, is defined by the equation $Z T=\sigma \alpha^{2} T / \kappa$. When the data for $\kappa$ is not available, the material can also be evaluated by the power factor $\left(P F=\sigma \alpha^{2}\right)$, which quantifies the ability of a given material to generate useful power, without comment on the efficiency. Simplistically it can be seen that to maximise $Z T$ an ideal material should have a high electrical conductivity $(\sigma)$ and a high Seebeck coefficient $(\alpha)$ leading to a high $P F$, and a low thermal conductivity $(\kappa)$. However, this clear message is complicated by the inherently conflicting nature of TE properties, posing a significant challenge for research into new materials. In summary, a high $\sigma$ generally leads to a low $\alpha$ and a high $\kappa$, so the fine-tuning of properties is of utmost importance to finding the correct balance that will lead to the highest efficiency. A detailed discussion of the theoretical aspects of TE materials and devices goes beyond the scope of this review. The reader is referred to a number of comprehensive books and reviews recently published in the literature ${ }^{[3,27,32,53-58]}$.

(a)

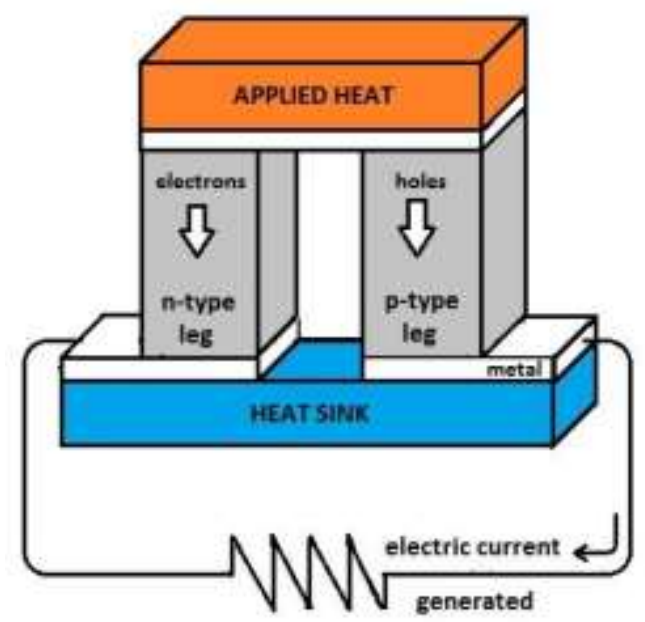

(b)

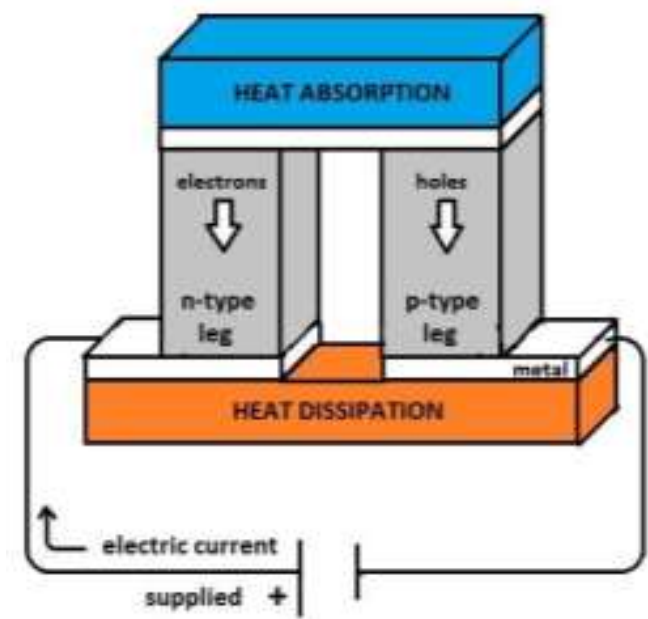

Figure 2: Basic structure of a typical thermoelectric device, with $p$ - and $n$-type thermocouples connected electrically in series and thermally in parallel for (a) power generation, and (b) refrigeration.

Different strategies have been pursued over the years to maximise ZT. The aim has often been to reduce $\kappa^{[36,59]}$ - for instance by promoting phonon scattering - while limiting the reduction in $\sigma$. 
Nevertheless, if a TE device for energy harvesting is to be made efficient, it is of paramount importance to maximise the $P F$ (in other words the nominator of the $Z T$ formula) rather than solely minimising the $\kappa$ (denominator of the $Z T$ formula). A $Z T$ value of about 1 is what the best inorganic materials can currently reach for room temperature applications. In 1999 DiSalvo set a challenging target for a wide spread commercial exploitation of TE devices, which is still far from reached. ${ }^{[60]} \mathrm{He}$ suggested that a device with a $Z T$ of 4 would compete with standard home refrigeration.

Another point should be considered at this moment concerning the material performance. The methodologies used to characterize the parameters of $Z T$ are complex procedures, particularly the specific heat measurements based on the laser flash method needed for calculating thermal conductivity. As quoted by Zebarjadi et al (2012) there has been issues with irreproducible data reported in the past, which is exacerbated by the fact that some papers do not fully disclose their measurement techniques making it a very difficult task to check the accuracy of the values claimed. [56] According to Rowe (2010), there is a considerable need for implementation of common measurement protocols and this would be the only route to guarantee accuracy level of results required for a wider application of the technique. ${ }^{[58]}$ Recent round robin tests have been conducted, highlighting some of these difficulties in particular with the measurement of accurate specific heat values. Detailed testing protocols have been presented in an effort to standardise measurements. ${ }^{\text {[61-62] }}$ We note that the value of similar efforts in the reporting of efficiency in the related field of organic photovoltaics have been widely recognised ${ }^{[63,64]}$

\section{POLYMER BASED THERMOELECTRIC MATERIALS}

The utilization of conjugated polymers as the semiconducting component is a relatively new concept in the field. The first European Conference on Thermoelectrics in 1988 had no mention on organic materials in their proceedings ${ }^{[65]}$, but according to the Thomas Reuter Web of Science citation report for the term 'organic thermoelectric*' (Figure 3), the interest has been growing exponentially over the last two decades. There are considerable potential advantages driving the investigation of these alternative materials such as lower cost, relative abundance and the possibility for large area deposition by various printing techniques. However, conjugated polymers generally have a low stability at high temperature, so their use is limited to lower-temperature applications. 

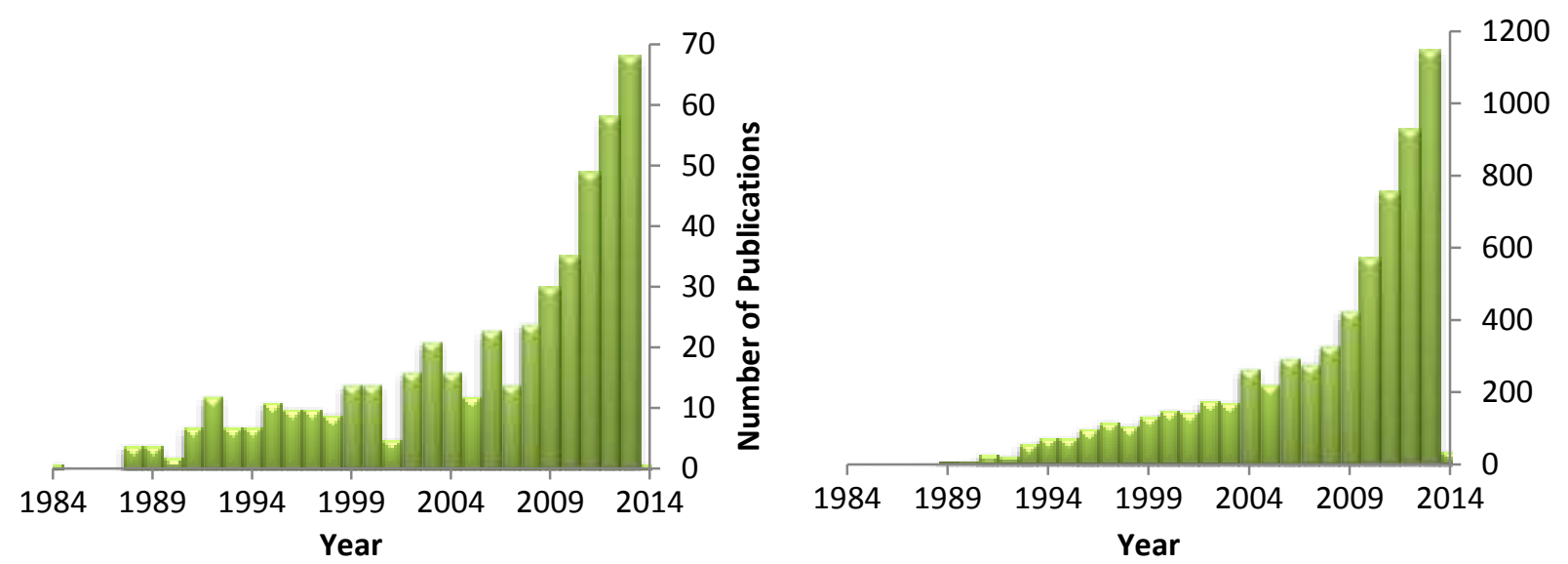

Figure 3: Thomson Reuters Web of Science citation report for the topic "Organic Thermoelectric*" for the last 30 years.

On this optimistic note, conjugated polymers are made of abundant elements and their molecular structure can be easily modified to tune desirable physical and chemical properties ${ }^{[66]}$. The inherently low thermal conductivity of polymeric materials is an advantageous characteristic, with values considerably lower than most inorganic counterparts, although the electrical conductivity is likewise more modest. It was only in 1977 that an enhanced $\sigma$ was reported for doped polyacetylene over a range of eleven orders of magnitude ${ }^{[67]}$. No connection with thermoelectricity was made at that point but conjugated polymers were put on the map as potential conductive materials for plastic electronic applications. The fine tuning of dopant concentrations (oxidation level) was later confirmed to be one of the best approaches for optimization of thermoelectric properties and in the late 1980s polyacetylene was first investigated for this purpose ${ }^{[68]}$. Poor environmental stability excluded this polymer as a potential candidate ${ }^{[58]}$ but related materials were soon investigated, with substantial research being performed with polyaniline, polycarbazole, polypyrrole, polythiophene, poly(alkylthiophene) and many others ${ }^{[66]}$, as well as the incorporation of semi-conducting nanoparticles into a polymeric matrix. However most of these materials produced modest figures of merit and up until 2011 a maximum ZT of 0.25 was reported for $p$-type polymer. ${ }^{[69]}$. The surge of interest in the last three years has resulted in some notable advances, principally the results of careful manipulation of the doping levels in $p$-type PEDOT/PSS ${ }^{[70]}$ and PP-PEDOT/Tos ${ }^{[71]}$ films, affording impressive $Z T_{\mathrm{RT}}$ values of 0.42 and 1.02 , respectively. The last result was based on thermal conductivity data reported for the compound by another source ${ }^{[69]}$ and if this value is found to be reproducible, it promises to offer a viable alternative to inorganic materials. For $n$-type organic materials the best results so far have been with a powder processed inorganic hybrid polymer, poly $\left[\mathrm{K}_{\mathrm{x}}(\mathrm{Ni}\right.$-ett $\left.)\right]$, with a $Z T$ value of 0.2 at $400 \mathrm{~K} .{ }^{[72]}$

An interesting issue for polymeric materials is that the parameters affecting $Z T$ can be significantly influenced by the conformational order of orientation of the material. For example, thermal 
conductivity can be anisotropic for polymers as their structures can assume different degrees of order depending on the processing conditions. According to Bubnova and Crispin (2012), the ratio of $\kappa / /$ and $\kappa \perp$ can be as large as four for spin coated polyimide films and ten for extruded polyethylene. ${ }^{[58]}$ No systematic studies have been performed on the relationship of $\kappa$ with crystallinity for conjugated polymers as far as we are aware. This information would be of great importance in bringing an insight into the best material structures able to scatter phonons without significantly disrupting the electrical conductivity, which is needed to increase $Z T .{ }^{[32]}$ Of course the influence of processing conditions on the solid-state microstructure of many conjugated polymers has been well investigated in the context of field-effect transistors (FETs) or organic solar cells. In organic thermoelectric devices this issue is further complicated by the general need to dope the semiconductor in order to increase the electrical conductivity. The use of organic molecular dopants therefore leads to binary mixtures of the polymer and dopant. Understanding of the phase behaviour of such mixtures is of critical importance to optimising the ZT, and issues such as dopant miscibility, phase segregation, and long-term stability will all need to be addressed and optimised. Fortunately, we believe there are many overlaps with the organic photovoltaic area, where the development of methods to control the solid-state microstructure and understanding of the phase behaviour of single-component systems as well as polymer/fullerene mixtures have been the subject of much attention. For example one of us was able to show simple rationale for the optimum composition of poly(3-hexylthiophene)/fullerene solar cell devices through the study of phase behaviour diagrams in terms of the classical understanding of eutectic solidification ${ }^{[73]}$. This approach could possibly be considered and adapted to some semi-crystalline materials when investigating the interactions between polymer and dopant.

There are many examples emphasising the effect of polymer structure on electrical performance; particularly in OPVs and FETs where processing solvents are known to have a significant influence on the ultimate device performance. Similarly, post-deposition procedures such as thermal or solvent annealing have a significant influence on performance. Of the various processing tools exploited in the OPV and FET area, we highlight one example here, which we believe may be particularly amenable to the formation of films of desirable thicknesses for TE devices and promises control of the degree of crystallinity of such structures, and that is solid state processing. In this technique a range of semiconducting organic polymers and small molecules were heated above their glass transition temperatures but below their melting temperatures whilst exerting moderate compressive force. This resulted in the formation of highly orientated thin films through material flow in the solid state ${ }^{[74]}$. The bulk electrical conductivity of such films was shown to be significantly higher than that of solution case films of the same material, most likely as a result of the improved molecular order (Figure 4). 

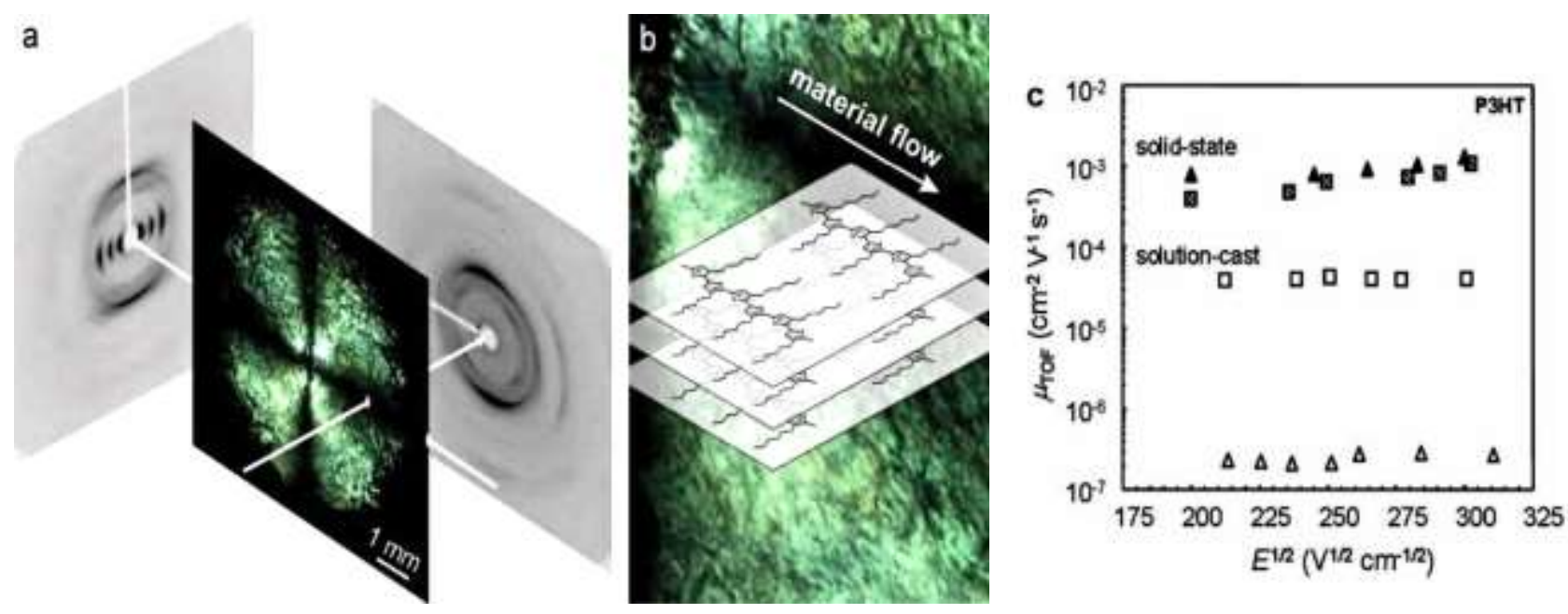

Figure 4: Solid-state compression moulding of P3HT: (a) polarized optical reflection micrograph and WAXD perpendicular and in the plane of the film, (b) molecular arrangement of P3HT macromolecules showing material flow during processing, (c) corresponding Poole-Frenkel plots of solid-state models ( $\boldsymbol{\square}$ and $\boldsymbol{\Delta}$ ) and solution-cast ( $\square$ and $\Delta$ ) of different molecular weights showing higher $\mu$ for solid-state processing, which is desirable for improving the power factor $\left(\alpha^{2} \sigma\right)$ of TE material, and consequently increasing ZT. Reproduced with permission from ref. [73]. Copyright 2010 Wiley-VCH Verlag GmbH E Co. KGaA.

In the remainder of this review we highlight the advances made with various conjugated polymers under different processing conditions. There have been several excellent reviews with comparison of experimental results for a diverse number of materials, so here we briefly highlight the important results for key material classes, as well as review recent progress since these previous publications $[29,57,66]$. A compilation of the reported TE properties for the polymers investigated is presented at the end of this article (Table 1).

\section{- Polyacetylene}

Polyacetylene was one of the first conjugated polymers investigated for TE applications. The best results were observed for stretch-aligned polyacetylene films doped with $\mathrm{FeCl}_{3}$, giving $\sigma_{\max }=30,000$ $\mathrm{S} \mathrm{cm}^{-1}$ at $220 \mathrm{~K} .{ }^{[68]}$ A clear anisotropic effect was observed with a high ratio of $100(\sigma / / / \sigma \perp)$. The polymer was later investigated with different dopants and the best result found for $28 \%$ iodine doped polyacetylene was $\sigma_{R T} \sim 10,000 \mathrm{~S} \mathrm{~cm}^{-1}$. ${ }^{[75]}$ In this article the $P F$ was also analysed and found to be higher at low doping levels $(\sim 0.8 \%)$, with $\alpha$ around $120 \mu \mathrm{V} \mathrm{K}^{-1}$. The transport in highly doped polyacetylene was concluded to be more consistent with metallic conduction models. Studies on the thermal conductivity of polyacetylene film were also performed, showing a smaller $\kappa=0.21 \mathrm{~W} \mathrm{~m}^{-1}$ $\mathrm{K}^{-1}$ for the cis-isomer, whereas $\kappa=0.38 \mathrm{~W} \mathrm{~m}^{-1} \mathrm{~K}^{-1}$ for the trans-isomer. ${ }^{[76]}$ This difference has been associated with variations in lattice heat conduction in these isomers. After doping to metallic regime, the $\kappa$ of the $c i s$-isomer increased to $0.69 \mathrm{~W} \mathrm{~m}^{-1} \mathrm{~K}^{-1}$, which can be related to the doping-induced isomerisation of the vinylene bond. 


\section{- Polypyrrole}

An early experiment on the thermoelectric properties of polypyrrole doped with silver $p$ toluenesulfonate (tosylate; Tos) at different doping levels was performed with electrochemically grown films. ${ }^{[77]}$ The reported $\sigma$ was low and ranged from $8 \mathrm{~S} \mathrm{~cm}^{-1}$ to $26 \mathrm{~S} \mathrm{~cm}^{-1}$ for lightly doped to normally doped films, respectively. A value of $\alpha=5 \mu \mathrm{V} \mathrm{K}^{-1}$ was achieved at $200 \mathrm{~K}$, reaching a maximum of about $7.2 \mu \mathrm{V} \mathrm{K}^{-1}$ at $300 \mathrm{~K}$ for lightly doped films. The term 'dedoping' was first detected chronologically in this survey, with the polymer film prepared using pyrrole monomers and silver $p$ toluenesulfonate by electrochemical polymerization at a constant voltage, then subsequently 'dedoped' by reversing the current, which resulted in the removal of some of the anions. Similar procedures with other polymers later proved to be highly efficient for optimizing the material TE properties and consequently increasing $Z T$.

Subsequent studies included investigations of $\sigma$ and $\alpha$ for a wide range of polypyrroles measured as a function of the temperature, ${ }^{[78]}$ the electrical property of their composites ${ }^{[79]}$, the effect of ammonia ${ }^{[80]}$, and the use of different doping agents ${ }^{[81,82]}$, but to date only modest conductivity and thermoelectric power values have been reported for these materials.

\section{- Polyaniline}

Polyaniline (PANI) has also received substantial attention due to reports of high conductivity. In 1997 the $\sigma$ of films prepared with camphorsulfonic acid (CSA) at different doping levels ranging from 10 to $90 \%$ was measured as a function of the temperature $(10 \text { to } 300 \mathrm{~K})^{[83]}$. A $\sigma_{M A X}$ of $268 \mathrm{~S} \mathrm{~cm}^{-1}(135$ K) for $60 \%$ doped films was reported. The value increased to $583 \mathrm{~S} \mathrm{~cm}^{-1}(215 \mathrm{~K})$ when the film was stretch oriented, although these results are still fractional when compared to polyacetylene. Subsequent experiments showed a thermal conductivity of PANI-CSA as low as $0.20 \mathrm{~W} \mathrm{~m}^{-1} \mathrm{~K}^{-1}$ for the through-plane direction $(\kappa / /)$ and $0.67 \mathrm{~W} \mathrm{~m}^{-1} \mathrm{~K}^{-1}$ for in-plane direction $(\kappa \perp)$, with an estimated ZT// of 0.001. ${ }^{[84]}$

It was reported at the $21^{\text {st }}$ International Conference on Thermoelectrics that the thermopower and electric conductivity of spin-coated polyaniline films had a tendency to increase with decreasing thickness of the film, leading to a $Z T_{M A X}$ of 0.029 for thinner films and $Z T_{M A X}$ of 0.0044 for the thicker ones. ${ }^{[85]}$ The anisotropic TE properties parallel and perpendicular to the stretched films were later reported, with a higher $Z T$ in the direction parallel to the stretching. ${ }^{[86]}$ This was explained by the coillike conformation of the extended polyaniline molecules leading to an increase of carrier mobility under almost constant carrier concentration. 
Many other articles have been published on the topic ${ }^{\left[{ }^{87-89]}\right.}$ but no significant $Z T$ values have yet been reported for doped polyaniline, or for composites with $\mathrm{Bi}_{2} \mathrm{Te}_{3}$ nanoparticles ${ }^{[00]}$ or exfoliated graphene nanoplatelets (GNP) ${ }^{[91]}$. For the first composite, $\sigma$ reduced compared to pristine film, although $\alpha$ was about one order of magnitude higher for the hybrid films. Physical mixture rather than solution mixture led to the highest $P F$ of $51 \mu \mathrm{W} \mathrm{m} \mathrm{m}^{-1} \mathrm{~K}^{-2}$ at $350 \mathrm{~K}$ (Figure 5), about 50 times higher than pristine PANI and marginally higher than GNP composite $\left(33 \mu \mathrm{W} \mathrm{m}^{-1} \mathrm{~K}^{-2}\right)$.

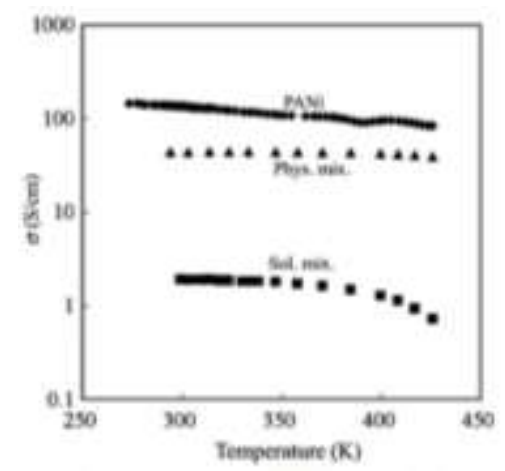

(a)

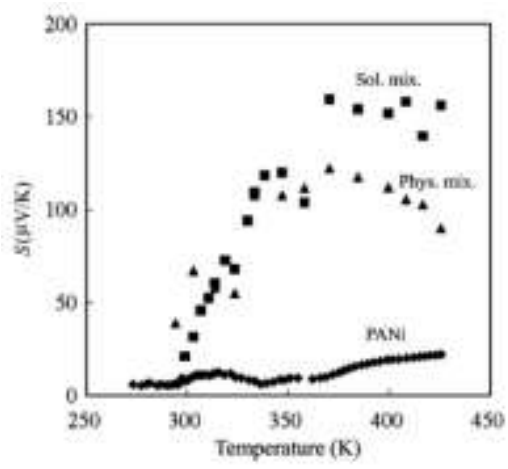

(b)

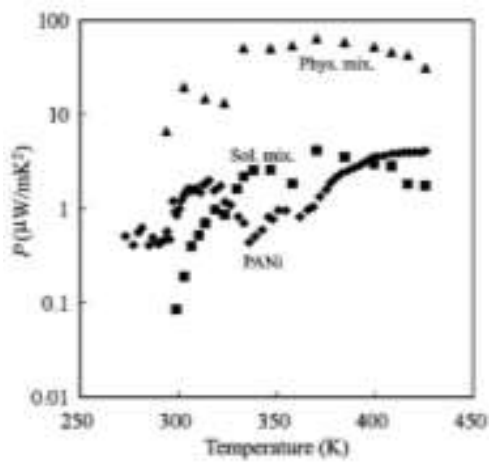

(c)

Figure 5: (a) Electrical conductivity and (b) Seebeck coefficient and (c) power factor of hybrid films of polyaniline and $\mathrm{Be}_{2} \mathrm{Te}_{3}$ nanoparticles, prepared by physical mixture and solution mixture, as well as a doped polyaniline film as a reference, over a range of ca. $300 \mathrm{~K}$ to $425 \mathrm{~K}$. Reprinted with permission from Springer: Journal of Electronic Materials from ref [90], copyrights 2010.

\section{- Poly(2,7-carbazole) derivatives}

Considerable research has been performed with poly(2,7-carbazole), poly(indolo[3,2-b]carbazole) and poly(diindolocarbazole) derivatives as well as copolymers ${ }^{[66]}$. It has been shown that the nature of the side chain on the nitrogen is important not only for increasing the solubility of the polymer but also to improve their molecular organisation in thin films. The best $\sigma$ of a poly(2.7-carbazole) derivative reported was up to $500 \mathrm{~S} \mathrm{~cm}^{-1}$ when doped with $\mathrm{FeCl}_{3}$, and $\alpha$ was up to $70 \mu \mathrm{V} \mathrm{K}^{-1}$. ${ }^{[91]}$ The best compromise between these two parameters lead to a maximum $P F$ of $19 \mu \mathrm{W} \mathrm{m} \mathrm{m}^{-1} \mathrm{~K}^{-2}$ for 2,7carbazole-based copolymers with benzothiadiazole. Nevertheless, this value is nearly 3 times lower than the best results found for polyaniline. In an earlier study, a very high Seebeck coefficient of 600 $\mu \mathrm{V} \mathrm{K}^{-1}$ was reported for a poly(2,7-carbazolenevinylene) at low doping levels, but the highest obtained $\sigma$ was $0.005 \mathrm{~S} \mathrm{~cm}^{-1}$, which significantly compromised the $P F .{ }^{[93]}$ If the electrical conductivity could be increased for these polymers, perhaps by blending with nanocomposite fillers, without detriment to the Seebeck coefficient, thie could be an interesting way to increase the thermoepower. 


\section{- Polyphenylenevinylene derivatives}

Poly(2,5-dimethoxyphenylenevinylene) and copolymers doped with iodine were studied for their TE properties ${ }^{[94]}$. A $P F$ of $7.1 \mu \mathrm{W} \mathrm{m}^{-1} \mathrm{~K}^{-2}$ at $313 \mathrm{~K}$ was reported, higher than that of the PANI-CSA used as reference. Increase in the $P F$ to $30 \mu \mathrm{W} \mathrm{m}{ }^{-1} \mathrm{~K}^{-2}$ was also reported in this study for a stretch-aligned copolymer, $\mathrm{P}(\mathrm{MeOPV}-\mathrm{co}-\mathrm{PV})$. In a later study by the same authors, the use of a similar copolymer with longer side chains (ethoxy) was found to further improve performance, with the iodine-doped, stretched-aligned polymer exhibiting a ZT of 0.0987 at $313 \mathrm{~K}$, one of the best values at the time and said to be comparable to that of inorganic TE materials such as $\beta-\mathrm{FeSi}_{2}$. ${ }^{\text {95] }}$

\section{- Poly(metal 1,1,2,2-ethenetetrathiolate)}

The thermoelectric performance of amorphous metal coordination polymers containing 1,1,2,2ethenetetrathiolate (ett) was recently reported, with unprecedented results for $n$-type poly[ $\mathrm{K}_{\mathrm{x}}(\mathrm{Ni}$-ett)] having a $Z T$ of 0.2 up to $440 \mathrm{~K}$ (the highest temperature before the polymer started to markedly degrade). ${ }^{[72]} \mathrm{A}$ related $p$-type material, poly $\left[\mathrm{Cu}_{\mathrm{x}}(\mathrm{Cu}\right.$-ett $\left.)\right]$ had a more modest $Z T$ of 0.014 at $400 \mathrm{~K}$. These findings are significant, as most other higher performance organic materials developed so far are $p$-type. It should be noted that these materials are highly insoluble and were powder processed in these experiments. It is interesting to notice the decoupling of parameters for poly $\left[\mathrm{Cu}_{\mathrm{x}}(\mathrm{Cu}-\mathrm{ett})\right]$, having $\sigma$ and $\alpha$ increasing simultaneously with the increased temperature (Figure 6). In this article a TE module containing $35 \mathrm{n}$-p single couples were also fabricated, generating an output of up to 750 $\mu \mathrm{W}$ with a load resistance of $33 \Omega$ for a $\Delta \mathrm{T}$ of $82 \mathrm{~K}\left(T_{h}=423 \mathrm{~K}\right)$, claimed to be the highest power derived by organic TE device ever reported. 

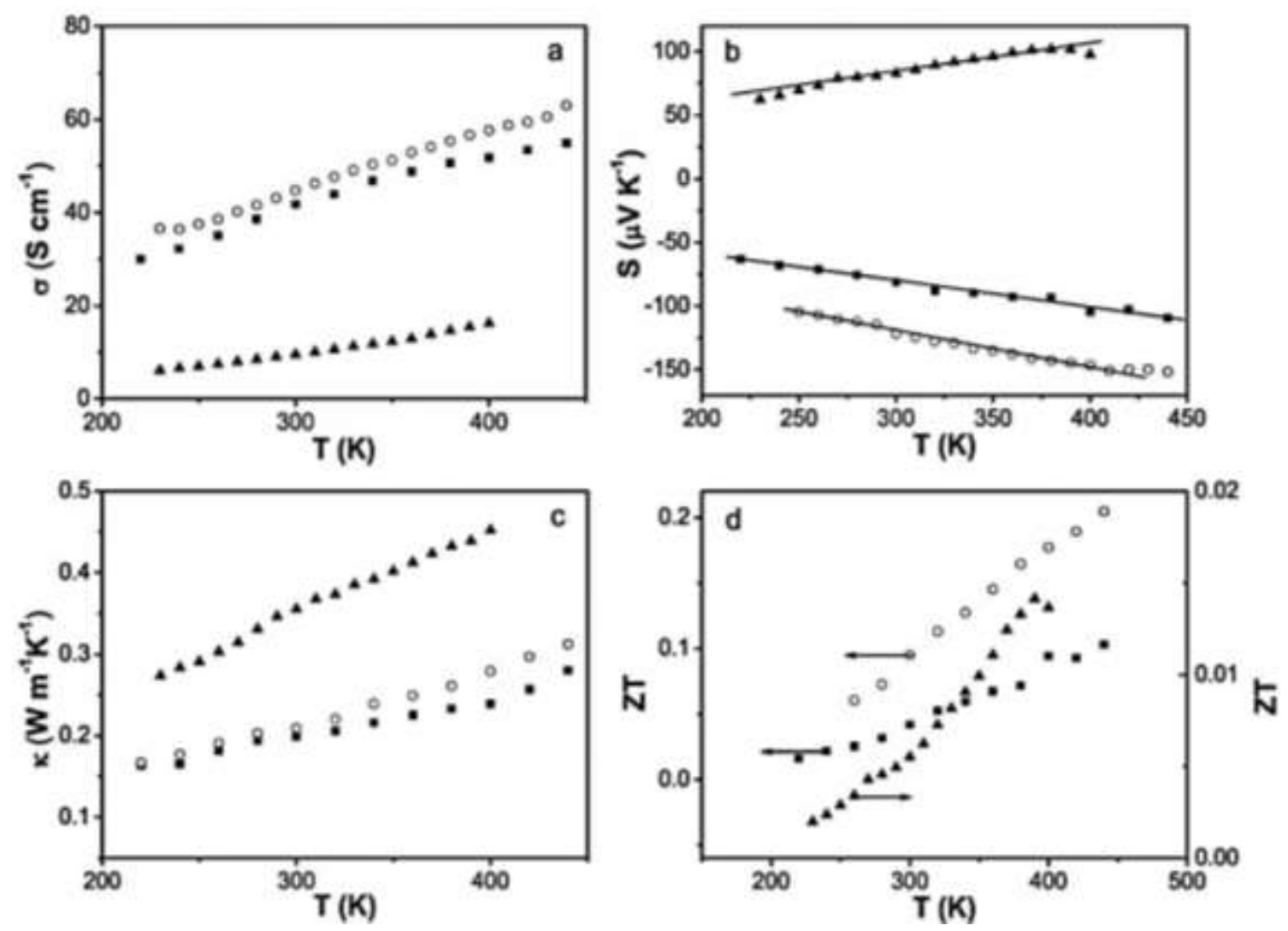

Figure 6: Temperature dependence of (a) electrical conductivity, (b) Seebeck coefficient, (c) thermal conductivity and (d)

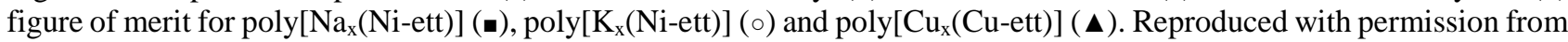
ref. [72] Copyright 2012 Wiley-VCH Verlag GmbH \& Co. KGaA.

\section{- Poly(alkylthiophene)}

Poly(3-alkylthiophene)s, and in particular poly(3-hexylthiophene) (P3HT), have been the subject of several investigations, perhaps driven by the high reported $\sigma$ of $1000 \mathrm{~S} \mathrm{~cm}^{-1}$ when regioregular P3HT was doped with $\mathrm{I}_{2 .}{ }^{\left[{ }^{96]}\right.} \mathrm{P} 3 \mathrm{HT}$ films doped with $\mathrm{NOPF}_{6}$ have since been studied at various temperatures from 220 to $370 \mathrm{~K}$. ${ }^{[97]}$ The $P F$ reached a broad maximum of $0.14 \mu \mathrm{W} \mathrm{m}{ }^{-1} \mathrm{~K}^{-2}$ between $20 \%$ and $31 \%$ doping levels, discussed in terms of thermally activated hopping-type mobility. The use of an alternative dopant, the ferric salt of the triflimide anion, was proposed as a more readily synthesised and environmentally benign dopant than nitrosonium-based alternatives. ${ }^{[98]}$ The high solubility of the dopant allowed ready doping of P3HT by simple solution immersion of the films into the solution of the salt, and the $P F$ was found to one order of magnitude higher than for films doped with $\mathrm{FeCl}_{3}$ or $\mathrm{NOPF}_{6}$, with respectable $Z T$ values of around 0.04 at $340 \mathrm{~K}$. This study highlights the opportunities for improvements in TE behaviour by careful selection of appropriate dopants and conterions, as well as polymers themselves. Unfortunately the doped film was still found to be somewhat moisture sensitive in this case.

The investigation of composite blends has been a popular route to try to improve performance. Encouraging results were recently reported for composites of P3HT and carbon nanotubes doped with 
$\mathrm{FeCl}_{3}$. ${ }^{\text {[99] }}$ Remarkable power factors of $95 \pm 12 \mu \mathrm{W} \mathrm{m}{ }^{-1} \mathrm{~K}^{-2}$ were observed for films with 42 to 81 wt\% single-walled carbon nanotubes (SWCNTs). Interestingly, despite the known high thermal conductivity of SWCNTs, the inclusion of around 8-10 wt\% did not compromise the thermal conductivity of the film with values close to that of the pristine polymer observed; the resulting figure of merit was at least ZT $>0.01$ at room temperature. Other scrutinized compounds of this category were poly(3-methylthiophene) ${ }^{[100]}$ and poly(3-octylthiophene) ${ }^{[101]}$ but to date no significant results showing a high figure of merit compared to other materials have yet been reported for this class of compounds.

\section{- PEDOT}

Poly(3,4-ethylenedioxythiophene) (PEDOT) has become one of the crown jewels of plastic electronics due to its outstanding properties in combination with an excellent environmental stability. The interest in this compound was substantiated by considerable research and development since the late 1990's. It has been commercialised in several current applications, including as an antistatic material in photographic films, electrode material in capacitors, hole injection layers in organic lightemitting diode (OLED) devices and many others ${ }^{[102]}$. PEDOT has also been claimed to give the highest TE performance to date for an organic compound when emulsified with tosylate or polystyrenesulfonate (PSS), followed by fine-tuning of oxidation level (dedoping).

PEDOT can be formed by the polymerisation of 3,4-ethylenedioxythiophene (EDOT) under electrochemical or chemical oxidation. Since the 3 and 4 positions of the thiophene ring are blocked by either substituents, coupling can only occur at the 2 and 5 positions. The polymer formed is insoluble, but this poor processability can be solved by performing the polymerisation in the presence of a charge-balanced electrolyte, commonly poly(styrenesulfonic acid) to give PEDOT:PSS emulsion, which has good film-forming properties. The PEDOT is positively doped and the sulfonate group balance this charge. PEDOT can also be formed directly on a substrate by vapour-phase polymerisation, in which the substrate coated with an oxidant, commonly $\mathrm{FeCl}_{3}$, or $\mathrm{Fe}$ (tosylate) 3 , is exposed to EDOT vapour. Very high conductivities over $1000 \mathrm{~S} \mathrm{~cm}^{-1}$ have been observed using this technique. ${ }^{[103]}$ These high conductivities require that the oxidant layer is coated with basic solution, to prevent undesired acid-catalysed polymerisation of EDOT, which gives non-conductive films.

A number of studies have shown that the conductivity of PEDOT:PSS or PEDOT:Tos films can be modified by exposure to a range of solvents, such as DMSO, DMF and THF and glycerol. ${ }^{[104,105]}$ The best results have been found by mixing aqueous PEDOT:PSS emulsions with various solvent additives, followed by thermal annealing of the resulting films, with conductivity changing by several 
orders of magnitude. The effect of these additives has been investigated in detail, and they are proposed to change the rather complex microstructure of PEDOT:PSS. Hence the dispersions are believed to consist of phase-segregated grains of highly conducting and hydrophobic regions rich in PEDOT surrounded by a shell formed by excess hydrophilic and insulating PSS. ${ }^{[106]}$ In aqueous solution, the chains are suggested to have a coil-like structure, and in the presence of conductivityboosting additives, it has been proposed that these compact coils expand, facilitating connectivity between grains in the final films. ${ }^{[107]}$

It should also be noted that the conductivity of PEDOT:PSS films is anisotropic with $\sigma \perp$ up to three orders of magnitude lower than the $\sigma_{/ /}$, which was reported to be isotropic in plane. ${ }^{[108]}$ The large difference in the magnitude of $\sigma$ was investigated as a function of temperature, with the $\sigma / /$ dependent on $\mathrm{T}^{1 / 4}$, interpreted in terms of a variable-range hopping model, whereas $\sigma \perp$ was dependent on $\mathrm{T}^{-1}$ and was interpreted in terms of a nearest-neighbour hopping-type behaviour. This was explained as a "pancake-like" model (Figure 7), in which grains are well interconnected in the lateral direction but less so in the vertical direction. According to Lang et al., the lamelas in the thin film can vary in thickness depending on the manufacturer of the compound. ${ }^{[106]}$ This could be reasoned by different molecular weights of the polymers, which can have a significant influence on the structure.
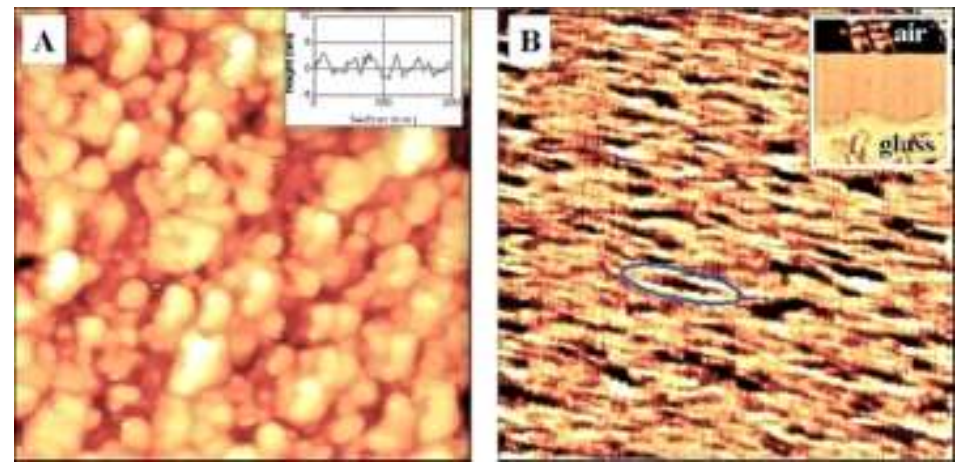

Figure 7: “(a) $200 \mathrm{~nm} \times 200 \mathrm{~nm}$ topographic STM image of PEDOT:PSS on indium tin oxide at 2.3 V, tunnelling current $10 \mathrm{pA}$, and vertical scale $15 \mathrm{~nm}$. The inset shows a line section. (b) $200 \mathrm{~nm} \times 200 \mathrm{~nm}$ cross-sectional AFM phase image of cleaved PEDOT:PSS on glass, vertical scale is $8^{\circ}$. The glass substrate is on the bottom side of the image, as shown by the inset of $530 \mathrm{~nm} \times 580 \mathrm{~nm}$ and vertical scale $70^{\circ}$. A pancake-like particle is highlighted by the ellipse." Reproduced with permission from ref. [108] Copyright 2007 Wiley-VCH Verlag GmbH \& Co. KG.aA

The thermoelectric performance of PEDOT:PSS thin films under the effect of DMSO and different molar ratios of PSS were investigated, showing that within the range studied, the variation of $\sigma$ overwhelmed the small variation of the $\alpha$, so the optimal $P F\left(0.8824 \mu \mathrm{W} \mathrm{m}^{-1} \mathrm{~K}^{-2}\right.$ for a molar ratio of $1: 2.5$ and $4.78 \mu \mathrm{W} \mathrm{m}^{-1} \mathrm{~K}^{-2}$ for the same molar ratio but with $5 \%$ DMSO as additive) was basically determined by the highest $\sigma$, which is approximately two orders of magnitude smaller than inorganic thermoelectric materials. ${ }^{[109]}$ A similar report for free-standing PEDOT:PSS film prepared from dispersions containing the additives DMSO or ethylene glycol (EG) showed a $\sigma$ of about $280 \mathrm{~S} \mathrm{~cm}^{-1}$ and excellent environmental stability containing the additives DMSO or EG prepared on a polypropylene film substrate. ${ }^{[110]}$ The solvent additives caused an increase of carrier mobility but did 
not result in changes of carrier concentration (as measured by the Hall measurement system), resulting in a $Z T$ up to 0.01 , claimed to be one order of magnitude higher than that of pressed pellets films.

An interesting approach to variable Seebeck coefficient and enhanced thermoelectric power of PEDOT:PSS films by blending the thermally decomposable ammonium formate (AF). ${ }^{[11]}$ The paper proposed that the thermal degradation process, which afforded gaseous byproducts, might result in the formation of pores or channels in the polymer, influencing thermal conductivity, as well as affecting carrier concentration by an unspecified mechanism. A maximum $\alpha$ value of $436.3 \mu \mathrm{V} \mathrm{K}^{-1}$ for $10 \% \mathrm{AF}$, claimed to be about 40 times higher in magnitude than the pure PEDOT:PSS film prepared using the same processes. This increased value is believed to be the result of a reduction of the carrier concentration, as evidenced by the Hall measurements, although the best $P F$ was only 0.69 $\mu \mathrm{W} \mathrm{m}{ }^{-1} \mathrm{~K}^{-2}$, which is lower than the best achieved with DMSO treatment reported in by Chang et al (2009) ${ }^{[109]}$.

The issue of dimensionality has also been investigated in PEDOT materials. Thus, ultra-long lithographically patterned and electrodeposited PEDOT nanowires of $40-90 \mathrm{~nm}$ in thickness, 150 $580 \mathrm{~nm}$ in width, and $200 \mu \mathrm{m}$ in length were investigated and compared to films deposited under the same conditions. The nanowire devices consistently outperformed the thin film analogues, with power factors and conductivities higher by a factor of 3. ${ }^{[112]}$

One of the best results for a polymer based TE material were found by Bubnova et al (2011). They suggested that an accurate control of the oxidation levels in PEDOT-Tos, which has an almost isotropic $\kappa$ of $0.37 \mathrm{~W} \mathrm{~m}^{-1} \mathrm{~K}^{-1}(\kappa \perp / \kappa / /=1.11)$, yielded a $Z T_{\mathrm{RT}}=0.25$ at about $22 \%$ oxidation level (Figure 8 ), approaching values required for efficient devices. ${ }^{[69]}$ The polymer was reduced in an inert atmosphere with tetrakis(dimethylamino)ethylene (TDAE), resulting in the transformation of positively charged (oxidized) polymer chains into neutral ones, with $\mathrm{TDAE}^{2+}$ subsequently forming a salt together with tosylate, which was easily removed from the film by rinsing with water. At room temperature, the charge-transport was described as governed by phonon-assisted hopping that allows a positive charge to move between sites in response to the vibrations of surrounding atoms. An all organic thermoelectric generator device consisting of $54 n-p$ legs of about $40 \mu \mathrm{m}$ high was produced with the resultant optimized $p$-type PEDOT/Tos and a non-optimized $n$-type TTF-TCNQ/PVC blend, providing a maximum power output of $0.128 \mu \mathrm{W}$ at $\Delta \mathrm{T}=10 \mathrm{~K}$, extrapolated to $0.27 \mu \mathrm{W} \mathrm{cm}$ ch $^{-2}$ at $=30 \mathrm{~K}$, claimed to be a sufficient scavenger to produce electrical power for medical sensors. 
(a)

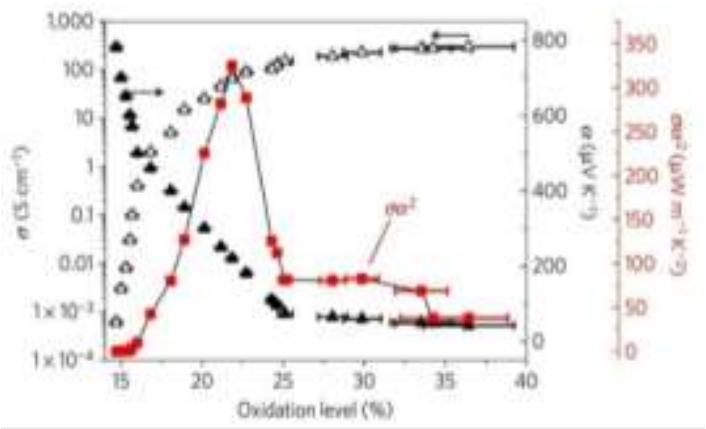

(b)

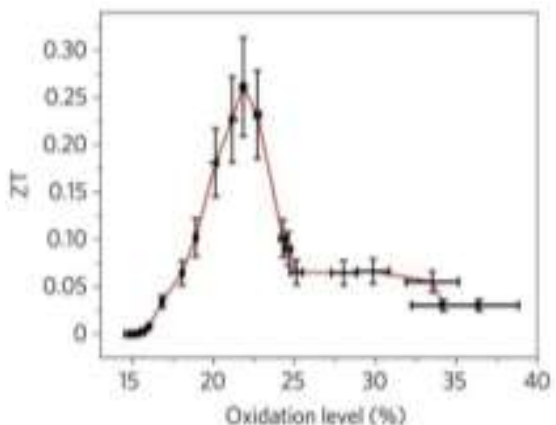

Figure 8: (a) Seebeck coefficient $\alpha$ (filled triangles), electrical conductivity $\sigma$ (open triangles) and corresponding power factor $\sigma \alpha^{2}$ (red squares) versus oxidation level, (b) Values of ZT at room temperature for various oxidation level assuming that the thermal conductivity of PEDOT-Tos is constant and equals $0.37 \mathrm{~W} \mathrm{~m}^{-1} \mathrm{~K}^{-1}$ (error from uncertainty in the lateral thermal conductivity (about 20\%). Reprinted by permission from Macmillan Publishers Ltd: Nature Materials from ref. [69], copyright 2011.

Another high performance result was reported for PEDOT/PSS by Kim et al (2013), with an impressive $Z T_{\mathrm{RT}}$ of $0.42 .{ }^{[70]}$ This was achieved by post-processing treatment of the high conductivity PEDOT:PSS films with hydrophilic solvents like ethylene glycol (EG) or (DMSO). These dissolves PSS but not PEDOT, thereby affording a route to a controlled physical dedoping. The removal of PSS was confirmed by XPS measurements and resulted in a reduction in film thickness and improvement in charge carrier transport. Decoupling of $\sigma$ and $\alpha$ was observed as the dedoping progressed, with simultaneous increase of both properties until about 100 minutes, whereas $\kappa$ was reduced in the same period (Figure 9).
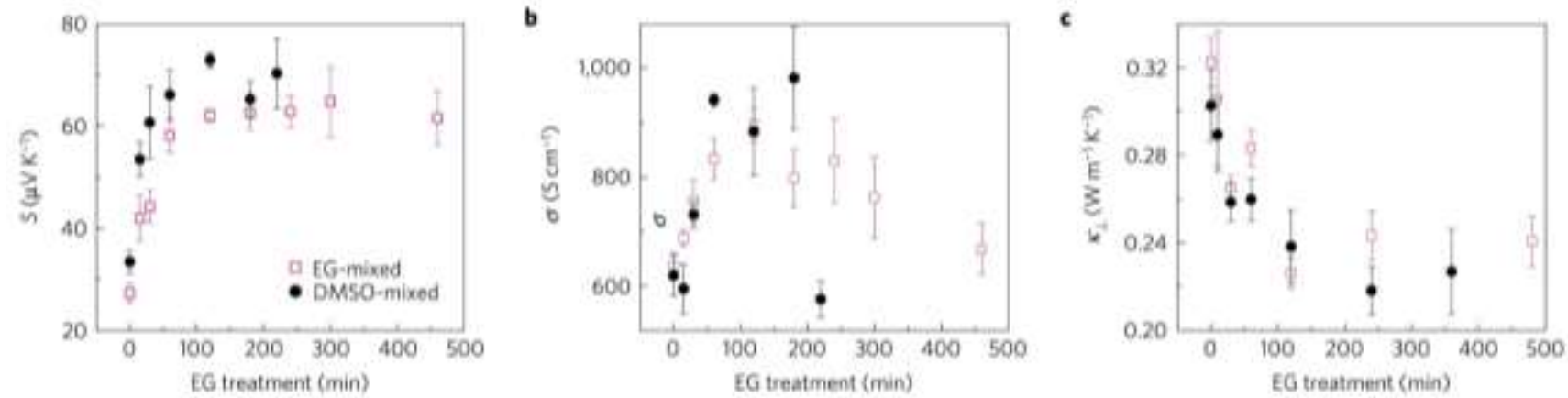
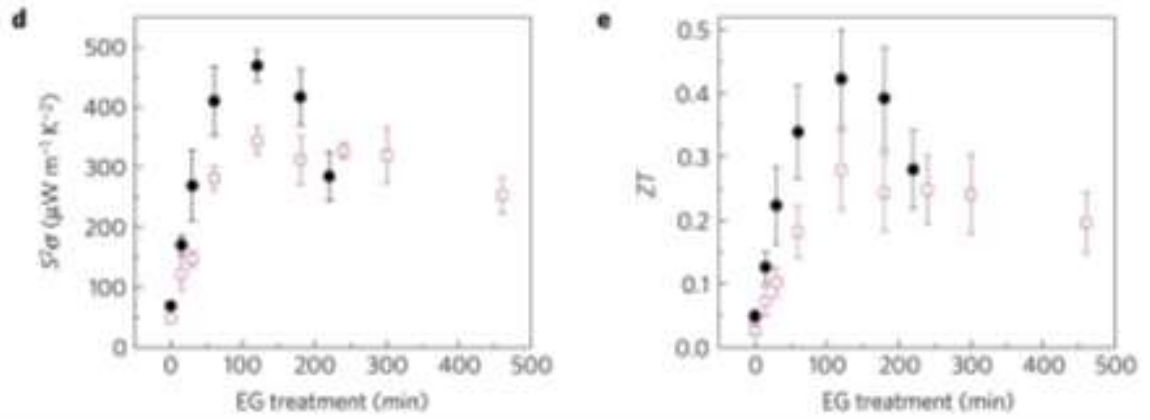

Figure 9: Thermoelectric properties of PEDOT:PSS at various dedoping times: (a) Seebeck coefficient, (b) electrical conductivity, (c) cross-plane thermal conductivity, (d) power factor and (e) figure of merit ZT at $274 \mathrm{~K}$ in EG-mixed and DMSO-mixed PEDOT:PSS measured during the dedoping process. Reprinted by permission from Macmillan Publishers Ltd: Nature Materials from ref. [70], copyrights 2013.

The performance of PEDOT has been enhanced even further in a recent study utilising electrochemically polymerised films prepared in situ. ${ }^{[71]}$ Here a butanol solution consisting of the 
oxidant $\left(\mathrm{Fe}(\mathrm{Tos})_{3}\right)$, a base (pyridine) to control the acidity, and a triblock polymer (poly(ethylene glycol The most remarkable performance was (poly(ethylene glycol)-block-poly(propylene glycol)block-poly(ethylene glycol): PEPG) and EDOT monomer was polymerised at $70^{\circ} \mathrm{C}$ directly on prepatterned gold electrodes for $2 \mathrm{~h}$. After polymerisation, the films were washed with ethanol to remove excess oxidant, low-weight oligomers and impurities. The role of the triblock polymer PEPG was unclear, but it was proposed to inhibit crystallisation of the oxidant as well as slow down the rate of polymerisation, thereby improving control. Its use was inspired by previous reports in vapour polymerisation. ${ }^{[113-115]}$ The film prepared in the presence of PEPG and pyridine (named PP-PEDOT) had a much higher conductivity than that prepared without the PEPG present, sufficiently high to allow its use as an electrode material itself. Importantly, this allowed for the precise control of the oxidation level. Films were grown on flexible PET substrates and exhibited an unprecedented $P F$ of $1,270 \mu \mathrm{W} \mathrm{m}{ }^{-1} \mathrm{~K}^{-2}$, sufficient for generating electricity from the human body (Figure 10). Considering a $\kappa$ of $0.37 \mathrm{~W} \mathrm{~m}^{-1} \mathrm{~K}^{-1}$ reported by another source ${ }^{[69]}$, the $Z T$ was estimated to be as high as 1.02 , which is comparable to most inorganic compounds for room temperature applications.
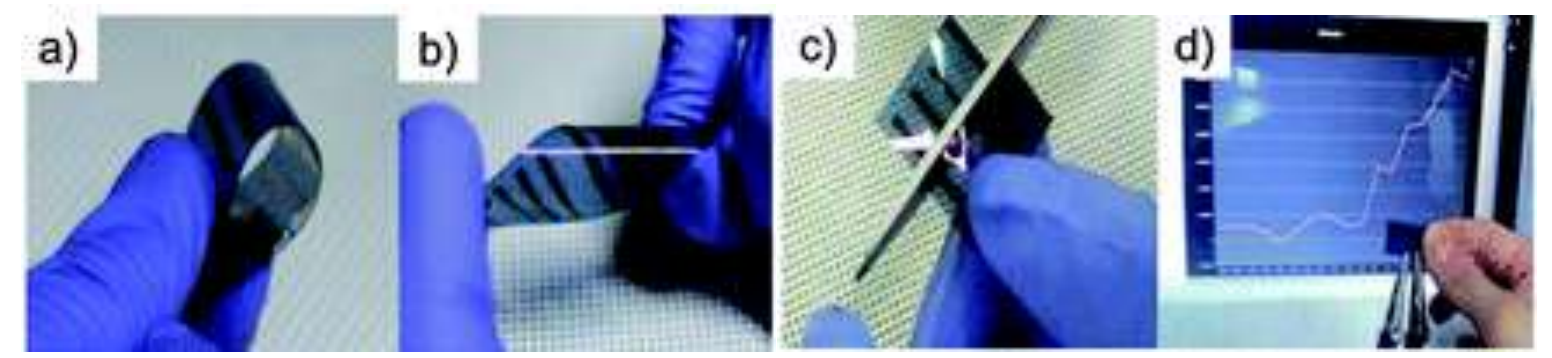

Figure 10: Photographic images and electricity generation by the touch of fingertips of the flexible PP-PEDOT TE film. (a) Bending, (b) twisting, (c) cutting with scissors and (d) electricity generation by fingertip touch. Reproduced from ref. [71] with permission from The Royal Society of Chemistry.

These recent experiments have demonstrated the promising potential of conjugated polymers such as PEDOT for thermoelectric applications, with the efficiency of this compound alone significantly increasing over the past few years as a result of consistent research (figure 11). Further investigations into the optimization of current materials, as well as the search for new compounds may help bringing forward this technology in a much faster pace than previously expected.

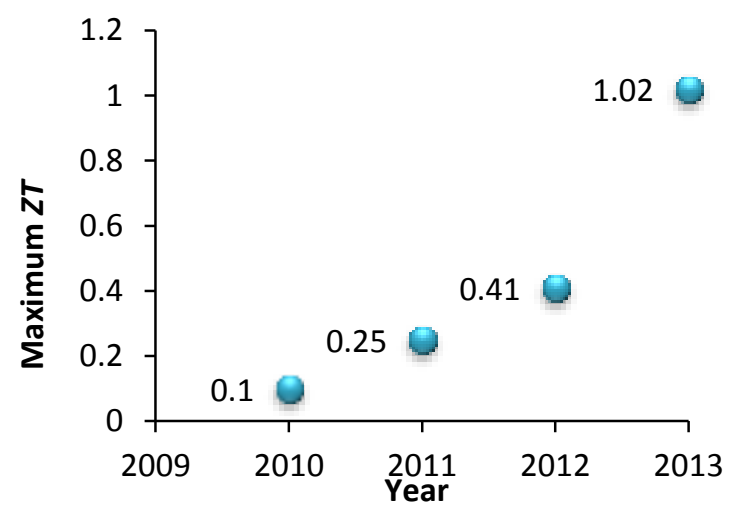

Figure 11: Maximum ZT value for PEDOT materials based on data reported in the literature in recent years. 


\section{- PEDOT-BASED NANOCOMPOSITES}

Much work have also been undertaken in the study of composite materials, but only modest improvements in TE properties have been reported compared to pristine compounds. For example, PEDOt nanorod clusters coated with PbTe nanoparticles (20 to $50 \mathrm{~nm}$ ) have been investigated and compared to the pure PEDOT nanorods. The composite and the pristine nanorods were prepared in situ by interfacial polymerisation. ${ }^{[116]}$ The materials were dedoped during purification, resulting in low conductivities but high negative Seebeck coefficients of $4,088 \mu \mathrm{V} \mathrm{cm}^{-1}$ for the pristine nanorods. Inclusion of $\mathrm{PbTe}$ was found to result in $\alpha$ but an increase in conductivity. The optimum performance

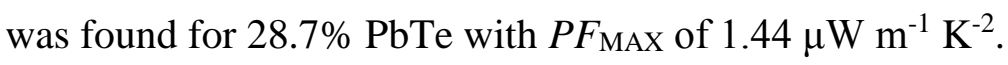

Improved thermoelectric behaviour was found for PEDOT/nanotube composites, with a reported $\sigma$ of up to $40 \mathrm{~S} \mathrm{~cm}^{-1}$ (35 wt\% SWCNT) without significantly affecting $\alpha$. Similar to the results for the P3HT composite, the thermal conductivity $\kappa$ remained comparable to typical polymeric materials despite the high thermal conductivity of SWCNTs. ${ }^{[117]}$ These decoupled properties were believed to be due to thermally disconnected and electrically connected contact junctions between CNTs. The highest estimated $Z T_{\mathrm{RT}}$ was $\sim 0.02$. This article has further demonstrated the drying temperature can also influence the thermoelectric properties, highlighting again the important relationship between processing, morphology and the final performance of the film. A related study of a similar composite achieved a $Z T_{\mathrm{RT}}$ of 0.03 for $40 \mathrm{wt} \%$ SWCNT exfoliated with PEDOT:PSS. ${ }^{[18]}$ In these cases the PEDOT:PSS effectively disperse the SWCNTs during sonication of mixtures of the two components, acting both as the surfactant to help prevent the hydrophobic nanotubes from aggregating and a a conductive pathway. Upon drying, electrically conductive junctions between the components was formed, resulting in enhanced TE properties (Figure 12).

(a)

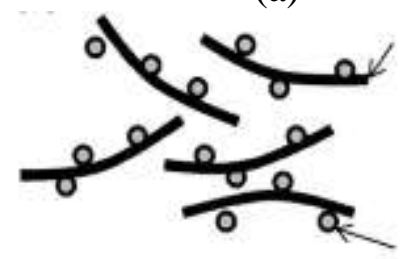

(b)

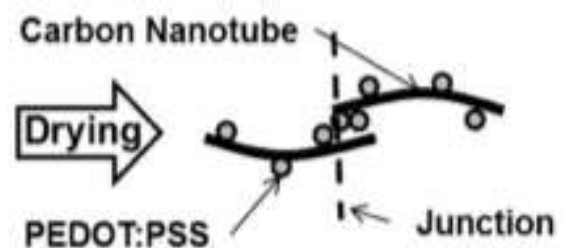

Figure 12: (a) Representation of exfoliated SWCNT coated by PEDOT:PSS particles, and (b) an electrically conductive junction formed between the SWCNT upon drying of the exfoliated solution. Reproduced with permission from ref. [118] Copyright 2012 Wiley VCH Verlag GmbH \& Co. KGaA.

Nanocomposite thin films prepared by spin-coating PEDOT:PSS with very low concentrations of graphene (1,2 and $3 \mathrm{wt} \%$ ) has also been investigated, With the best results at $2 \% \mathrm{wt} \%$ graphene having a $P F=11.09 \mu \mathrm{W} \mathrm{m}{ }^{-1} \mathrm{~K}^{-2}$ and a $Z T=0.021$. ${ }^{[55]}$ Analysis by XPS and Raman techniques 
demonstrated a strong $\pi-\pi$ interaction between the graphene and the PEDOT, facilitating the dispersion of the graphene. Similarly, composites of PEDOT:PSS with $\mathrm{Ca}_{3} \mathrm{Co}_{4} \mathrm{O}_{9}$, an oxide-based semiconductor showing some promise in TE, have been investigated as thin films. ${ }^{[119]}$ The $P F$ was shown to decrease with increasing $\mathrm{Ca}_{3} \mathrm{Co}_{4} \mathrm{O}_{9}$ content compared to the pristine film $\left(P F_{\mathrm{MAX}} \sim 6.3 \mu \mathrm{W}\right.$ $\mathrm{m}^{-1} \mathrm{~K}^{-2}$ at RT), mainly due to a decline of $\sigma$ and a limited improvement of $\alpha$. More impressive results have been reported from composites of tellurium nanorods functionalised with PEDOT:PSS, resulting in a $p$-type continuous network upon drop casting with and impressive $Z T_{\mathrm{RT}}$ of about $0.1 .^{[120]}$

Other approaches involved PEDOT and metal nanoparticles $\left(Z T=0.0163\right.$ at $50{ }^{\circ} \mathrm{C}$ for PEDOTAuNPs) ${ }^{[121]}$, as well as PEDOT:PSS films with the addition of a different gold nanoparticles (ZTMAX $=0.098$ at $120{ }^{\circ} \mathrm{C}$ with $0.01 \mathrm{mg} / \mathrm{ml} \mathrm{Au- \textrm {MH } _ { 2 } )}{ }^{[122]}$, PEDOT:PSS with added ionic liquids $(P F=9.9$ $\mu \mathrm{W} \mathrm{m}^{-1} \mathrm{~K}^{-2}, Z T_{\mathrm{RT}}=0.017$ with $70 \mathrm{wt} \%$ 1-butyl-3-methylimidazolium bromide) ${ }^{[123]}$, TE/PEDOT:PSS nanowire hybrid compositein $\left(P F=100 \mu \mathrm{W} \mathrm{m}{ }^{-1} \mathrm{~K}^{-2} \text { with } 5 \text { vol\% DMSO }\right)^{[124]}$, PEDOT:PSS/Bi $2 \mathrm{Te}_{3}$ films $\left(Z T=0.04 \text { at } 10 \mathrm{wt} \% \mathrm{Bi}_{2} \mathrm{Te}_{3}, \kappa=0.07 \pm 0.02 \mathrm{~W} \mathrm{~m}^{-1} \mathrm{~K}^{-1}\right)^{[125]}$, and many others. As demonstrated in this final summary of results, although some enhanced properties were observed for the composites, no significant improvement in the material figure of merit, compared to the chemical or electrochemical dedoping of PEDOT, was achieved. None of these experiments utilized the synergetic advantages of optimised polymers after dedoping alongside the addition of fillers and perhaps the combination of these two favourably contributing factors may further improve $Z T$ and should be a topic for future investigations.

\section{4 - SUMMARY AND OUTLOOK:}

A detailed summary of the results covered by this review is given in Table 1. Analysis of these data can be helpful in elucidating the principles governing the thermoelectric properties of different materials, and consequently may aid in the selection of new materials to be studied. As an example, in figure 13 we plot the trend of $P F$ vs. $\kappa$ for PEDOT-based materials (showing $Z T$ values represented by the size of the circle as a third parameter). A general trend of increased $P F$ with increased $\kappa$ is observed, demonstrating the conflicting nature of the parameters governing the efficiency of TE materials. Here the significant increase in $Z T$ is related to the $P F$ increasing by a higher order of magnitude than $\kappa$.

In conclusion, compared to the vast number of conjugated polymers, copolymers and small conjugated molecules investigated for plastic electronics applications, such as OPV, OLED, and OFET, the list of materials scrutinised for thermoelectric devices still seems quite modest. PEDOT has, so far, proved to be the most promising candidate, due to the ability to closely control the doping level. A significant 
challenge is the development of complementary n-type organic polymers, in part due to the paucity of stable extrinsic dopants for such electron-deficient materials. Nevertheless, the great advances made in the development of OPV and OFET materials bring significant understanding in the design and control of blend microstructures. Considerable effort must be invested in researching new materials, as well as understanding the role that parameters such as molecular weight, blend microstructure and charge transport have on the thermoelectric properties. This may also lead to a better understanding of the intrinsic correlations governing polymer semiconductors, making viable the overdue progress of this technology into an efficient and popular form of sustainable harvesting of green energy.

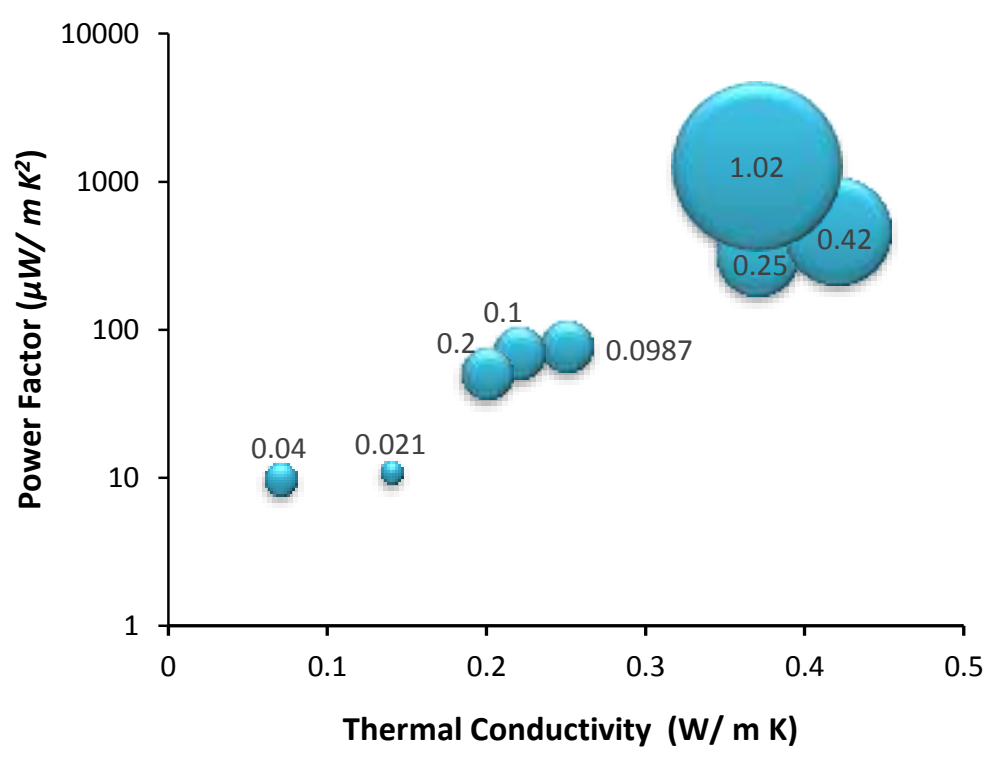

Figure 13: An example of data analysis that may help uncovering trends between TE properties of PEDOT materials. $P F$ $v s \kappa$ for eight reported results extracted from the literature surveyed (showing ZT values represented by the size of the circle as third parameter). 
Table 1: Thermoelectric properties for the conjugated polymers surveyed in this report.

\begin{tabular}{|c|c|c|c|c|c|c|c|c|}
\hline Material & $\begin{array}{l}\text { Production } \\
\text { process }\end{array}$ & $\begin{array}{c}\sigma \\
\left(\mathrm{S} \mathrm{cm}^{-1}\right)\end{array}$ & $\begin{array}{c}\alpha \\
\left(\mu V K^{-1}\right)\end{array}$ & $\begin{array}{c}\alpha^{2} \sigma \\
\left(\mu \mathrm{W} \mathbf{m}^{-1} \mathbf{K}^{-2}\right)\end{array}$ & $\begin{array}{c}\kappa \\
\left(\mathbf{W} \mathbf{m}^{-1} \mathbf{K}^{-1}\right)\end{array}$ & $\mathbf{Z T}$ & Comments & Ref \\
\hline PA: $\mathrm{FeCl}_{3}$ & $\begin{array}{l}\text { Solution doping of } \\
\text { free standing film } \\
\text { grown on } \\
\text { polypropylene } \\
\text { substrate. }\end{array}$ & $\begin{array}{c}30,000 \\
\text { MAX } \\
(220 \mathrm{~K})\end{array}$ & $\begin{array}{c}18.4 \\
(300 \mathrm{~K})\end{array}$ & - & - & - & $\begin{array}{c}\text { Stretch oriented, } \\
\text { anisotropy increases } \\
\text { with } \sigma \text { up to } \sigma_{/ /} / \sigma \perp= \\
100 \text { at } \sigma_{\mathrm{MAX}} \text {. }\end{array}$ & {$[68]$} \\
\hline $\begin{array}{l}\text { "New" PA: } \\
\text { Iodine }\end{array}$ & $\begin{array}{l}\text { Tetrabutoxy } \\
\text { titanium-triethyl } \\
\text { aluminium } \\
\text { catalysed } \\
\text { polymerization }\end{array}$ & $\begin{array}{l}10,000 \\
\text { MAX } \\
(\mathrm{RT}) \\
28 \% \mathrm{I}\end{array}$ & $\begin{array}{l}\sim 18 \\
\text { MAX } \\
(\mathrm{RT}) \\
27 \% \mathrm{I}\end{array}$ & - & - & - & When $\mathrm{T} \sim 0 \rightarrow \sigma \neq 0$ & [75] \\
\hline $\begin{array}{l}\text { "New" PA: } \\
\text { Iodine }\end{array}$ & $\begin{array}{l}\text { Tetrabutoxy } \\
\text { titanium-triethyl } \\
\text { aluminium } \\
\text { catalysed } \\
\text { polymerization }\end{array}$ & - & $\begin{array}{c}\sim 120 \\
\mathrm{RT} \\
0.8 \% \mathrm{I}\end{array}$ & - & - & - & $\begin{array}{c}\text { Little temperature } \\
\text { dependence from } 150 \\
\text { to } 300 \mathrm{~K} .\end{array}$ & {$[75]$} \\
\hline PA: Iodine & $\begin{array}{l}\text { High density film, } \\
\text { Shirakawa method. }\end{array}$ & $\begin{array}{l}40,000 \\
\text { MAX } \\
(\mathrm{RT})\end{array}$ & $\begin{array}{c}\sim 20 \\
(250 \mathrm{~K}) \\
\downarrow \text { doping }\end{array}$ & - & - & - & $\begin{array}{c}10 \mu \mathrm{m} \text { thickness PA } \\
\text { film stretched } 4 \sim 5 \\
\text { times. }\end{array}$ & [126] \\
\hline cis-PA & $\begin{array}{l}\text { Ito et al (1975) } \\
\text { method. }\end{array}$ & - & - & - & $\begin{array}{c}\kappa_{/ /}=0.21 \\
(\mathrm{RT})\end{array}$ & - & Pristine film. & {$[76]$} \\
\hline$c i s-\mathbf{P A}$ & $\begin{array}{l}\text { Ito et al (1975) } \\
\text { method. }\end{array}$ & - & - & - & $\begin{array}{c}\kappa_{/ /}=0.69 \\
(\mathrm{RT})\end{array}$ & - & $\begin{array}{l}\text { 10\% doped with } \mathrm{AsF}_{5} \text {, } \\
\text { increased lattice heat } \\
\text { conduction. }\end{array}$ & [76] \\
\hline trans-PA & $\begin{array}{l}\text { Ito } \text { et al }(1975) \\
\text { method. }\end{array}$ & - & - & - & $\begin{array}{c}\kappa_{/ /}=0.38 \\
\quad(\mathrm{RT})\end{array}$ & - & Pristine film. & [76] \\
\hline PPY:Tos & $\begin{array}{l}\text { Electrochemical } \\
\text { polymerization, } \\
\text { dedoping by } \\
\text { reverting the } \\
\text { current. }\end{array}$ & $8 \rightarrow 26$ & $\begin{array}{c}\sim 7.2 \rightarrow \\
6.5 \\
(\mathrm{RT})\end{array}$ & - & - & - & $\begin{array}{l}\text { Values for } \sigma \text { and } \alpha \text { : } \\
\text { lightly } \rightarrow \text { normally } \\
\text { doped. }\end{array}$ & [77] \\
\hline PANI:CSA & $\begin{array}{l}\text { CAS/ m-cresol } \\
\text { solution } \\
\text { processing route, } \\
\text { free standing film. }\end{array}$ & $\begin{array}{c}268 \\
\mathrm{MAX} \\
(135 \mathrm{~K})\end{array}$ & - & - & - & - & $\begin{array}{l}60 \% \text { doping level, } \\
\text { free standing film. }\end{array}$ & [83] \\
\hline PANI:CSA & $\begin{array}{l}\text { CAS/ m-cresol } \\
\text { solution } \\
\text { processing route, } \\
\text { free standing film. }\end{array}$ & $\begin{array}{l}583 \\
(\mathrm{RT})\end{array}$ & - & - & - & - & $\begin{array}{l}60 \% \text { doping level. } \\
\text { Stretched oriented film. }\end{array}$ & [83] \\
\hline $\begin{array}{c}\text { PANI:CSA } \\
(1: 1)\end{array}$ & $\begin{array}{l}\text { CAS/ m-cresol } \\
\text { solution } \\
\text { processing route, } \\
\text { drop cast film onto } \\
\text { quartz substrate. }\end{array}$ & $\begin{array}{c}200 \text { to } \\
400 \\
\text { (RT) }\end{array}$ & $\begin{array}{c}9 \\
(\mathrm{RT})\end{array}$ & - & $\begin{array}{c}\kappa_{/ /}=0.2 \\
\kappa \perp=0.67\end{array}$ & $\begin{array}{l}0.001 \\
\text { In } \\
\text { plane }\end{array}$ & $\begin{array}{l}\text { Emeraldine, } \mathrm{p} \text {-type } \\
\text { conduction, cast } \\
\text { dependent, } \mathrm{M}_{\mathrm{w}} \sim \\
80,000 .\end{array}$ & {$[84]$} \\
\hline $\begin{array}{c}\text { PANI } \\
\text { thin film }\end{array}$ & $\begin{array}{l}\text { m-cresol solution } \\
\text { processing, spin } \\
\text { coated films. }\end{array}$ & $\begin{array}{c}\sim 220 \\
\text { MAX } \\
(420 \mathrm{~K})\end{array}$ & - & - & - & $\begin{array}{l}0.029 \\
\text { THIN } \\
\text { FILM }\end{array}$ & $\begin{array}{l}\text { TE values decrease } \\
\text { with thickness of film, } \\
\qquad \mathrm{M}_{\mathrm{w}}=50,000\end{array}$ & [85] \\
\hline $\begin{array}{c}\text { PANI } \\
\text { different dopants }\end{array}$ & $\begin{array}{l}\text { CAS/ m-cresol } \\
\text { solution } \\
\text { processing route at } \\
\text { low temperature. }\end{array}$ & $\begin{array}{c}\sim 150 \\
(430 \mathrm{~K})\end{array}$ & $\begin{array}{c}\sim 38 \\
(430 \mathrm{~K})\end{array}$ & - & - & $\begin{array}{c}0.029 \\
(430 \mathrm{~K})\end{array}$ & $\begin{array}{l}\text { Stretched oriented, } \\
\text { increased } \mu \text {, thinner } \\
\text { films with higher } \sigma \text {. }\end{array}$ & [86] \\
\hline
\end{tabular}




\begin{tabular}{|c|c|c|c|c|c|c|c|c|}
\hline Material & $\begin{array}{c}\text { Production } \\
\text { process }\end{array}$ & $\begin{array}{c}\sigma \\
\left(\mathrm{S} \mathrm{cm}^{-1}\right)\end{array}$ & $\begin{array}{c}\alpha \\
\left(\mu \vee K^{-1}\right)\end{array}$ & $\begin{array}{c}\boldsymbol{\alpha}^{2} \sigma \\
\left(\mu \mathrm{W} \mathbf{m}^{-1} \mathbf{K}^{-2}\right)\end{array}$ & $\begin{array}{c}\kappa \\
\left(\mathbf{W} \mathbf{m}^{-1} \mathbf{K}^{-1}\right)\end{array}$ & ZT & Comments & Ref \\
\hline PANI: GNP & $\begin{array}{l}\text { In-situ } \\
\text { polymerization of } \\
\text { aniline in the } \\
\text { presence of GNP. }\end{array}$ & $\begin{array}{c}59 \\
50 \mathrm{mM}\end{array}$ & $\begin{array}{c}33 \\
50 \mathrm{mM}\end{array}$ & & $\begin{array}{c}13 \\
50 \mathrm{mM}\end{array}$ & $\begin{array}{c}1.51 \mathrm{x} \\
10^{-4} \\
50 \mathrm{mM}\end{array}$ & $\begin{array}{c}Z T \text { of composite }-2 \\
\text { orders of magnitude } \\
\text { higher than } \\
\text { constituents. }\end{array}$ & [91] \\
\hline $\begin{array}{c}\text { PC derivative: } \\
\mathrm{FeCl}_{3}\end{array}$ & $\begin{array}{l}\text { Copolymerization } \\
\text { with } \\
\text { benzothiadiazole } \\
\text { unit. }\end{array}$ & 160 & 34 & 19 & - & - & $\begin{array}{l}\text { Copolymer, longer } \pi \text { - } \\
\text { conjugation and planar } \\
\text { backbone. Values for } \\
\text { optimized data. }\end{array}$ & {$[66]$} \\
\hline $\begin{array}{c}\text { PC derivative: } \\
\mathrm{FeCl}_{3} \text { low doping }\end{array}$ & $\begin{array}{l}\text { Leclerc et al } \\
\text { (2004) method. }\end{array}$ & $\begin{array}{c}0.005 \\
\text { Low } \\
\text { doping }\end{array}$ & $\begin{array}{c}200 \rightarrow \\
600\end{array}$ & - & - & - & $\begin{array}{l}\alpha=\text { high } \rightarrow \text { low } \\
\text { doping, } \\
\text { highly soluble, alkyl } \\
\text { side chains. }\end{array}$ & [93] \\
\hline PMeOPV & $\begin{array}{c}\text { Thermal elimination } \\
\text { reaction. }\end{array}$ & $\begin{array}{c}46.3 \\
(313 \mathrm{~K})\end{array}$ & $\begin{array}{c}39.1 \\
(313 \mathrm{~K})\end{array}$ & $\begin{array}{c}7.1 \\
(313 \mathrm{~K})\end{array}$ & - & - & $\begin{array}{c}\text { Iodine doped, } \\
\text { stretching failed. }\end{array}$ & [94] \\
\hline $\begin{array}{c}\text { P(MeOPV-co- } \\
\text { PV) }\end{array}$ & $\begin{array}{c}\text { Thermal elimination } \\
\text { reaction. }\end{array}$ & $\begin{array}{c}183.5 \\
(313 \mathrm{~K})\end{array}$ & $\begin{array}{c}43.5 \\
(313 \mathrm{~K})\end{array}$ & $\begin{array}{c}34.8 \\
(313 \mathrm{~K})\end{array}$ & - & - & $\begin{array}{c}\text { Iodine doped, } \\
\text { stretching increase } \sigma \\
\text { and keep } \alpha \text { nearly } \\
\text { constant. }\end{array}$ & [94] \\
\hline P(EtOPV-co-PV) & $\begin{array}{c}\text { Thermal elimination } \\
\text { reaction. }\end{array}$ & $\begin{array}{c}349.2 \\
(313 \mathrm{~K})\end{array}$ & $\begin{array}{c}47.3 \\
(313 \mathrm{~K})\end{array}$ & $\begin{array}{c}78.1 \\
(313 \mathrm{~K})\end{array}$ & $\begin{array}{c}0.25 \\
(313 \mathrm{~K})\end{array}$ & $\begin{array}{l}0.0987 \\
(313 \mathrm{~K})\end{array}$ & $\begin{array}{l}\text { Iodine doped, } 3.1 \\
\text { stretching ratio. }\end{array}$ & [95] \\
\hline $\operatorname{poly}\left[K_{x}(N i-e t t)\right]$ & $\begin{array}{c}\mathrm{C}_{2} \mathrm{~S}_{4}^{4-}+\text { transition } \\
\text { metal salts. }\end{array}$ & $\begin{array}{c}\sim 63 \\
(440 \mathrm{~K})\end{array}$ & $\begin{array}{l}-151.7 \\
(440 \mathrm{~K})\end{array}$ & - & $\begin{array}{c}\sim 0.31 \\
(440 \mathrm{~K})\end{array}$ & $\begin{array}{c}0.2 \\
(440 \mathrm{~K})\end{array}$ & $\begin{array}{l}n \text {-type amorphous, } Z T \\
\text { increases with } \\
\text { temperature. }\end{array}$ & [72] \\
\hline $\begin{array}{c}4 \text { poly }\left[\mathrm{Cu}_{x}(\mathrm{Cu}-\right. \\
\text { ett })]\end{array}$ & $\begin{array}{c}\mathrm{C}_{2} \mathrm{~S}_{4}{ }^{4-}+\text { transition } \\
\text { metal salts. }\end{array}$ & $\begin{array}{c}\sim 15 \\
(400 \mathrm{~K})\end{array}$ & $\begin{array}{c}\sim 100 \\
(400 \mathrm{~K})\end{array}$ & - & $\begin{array}{c}\sim 0.45 \\
(400 \mathrm{~K})\end{array}$ & $\begin{array}{c}0.014 \\
(400 \mathrm{~K})\end{array}$ & $\begin{array}{l}n \text {-type amorphous, } Z T \\
\text { increases with } \\
\text { temperature. }\end{array}$ & [72] \\
\hline P3AT: $\mathbf{I}_{2}$ & $\begin{array}{l}\text { McCullough } \\
\text { method. }\end{array}$ & $\begin{array}{l}1000 \\
\text { MAX }\end{array}$ & - & - & - & - & $\begin{array}{c}\text { Regio-regular, highly } \\
\text { ordered PDDT, } \mathrm{M}_{\mathrm{W}} \\
11,600 \text { to } 16,000 .\end{array}$ & [96] \\
\hline $\begin{array}{c}\text { P3HT:NOPF } \\
\text { acetonitrile }\end{array}$ & $\begin{array}{l}98.5 \% \text { purity } \\
\text { dissolved in } \\
\text { chloroform formed } \\
\text { by drop casting on } \\
\text { glass substrate. }\end{array}$ & $\begin{array}{c}\sim 1 \\
(\mathrm{RT})\end{array}$ & $\begin{array}{l}\sim 25 \\
(\mathrm{RT})\end{array}$ & $\begin{array}{r}0.14 \\
\text { MAX } \\
(\mathrm{RT})\end{array}$ & - & - & $\begin{array}{c}p \text {-type } \sim 31 \% \text { chemical } \\
\text { doping with } \text { NOPF }_{6} \\
\text { thermally activated } \\
\text { mobility of bipolarons. }\end{array}$ & [97] \\
\hline P3HT: TFSI & $\begin{array}{c}\text { Systematic } \\
\text { immersion in } \\
\text { dopant at different } \\
\text { doping times }\end{array}$ & $\begin{array}{c}\sim 93 \\
(340 \mathrm{~K})\end{array}$ & $\begin{array}{c}\sim 50 \\
(340 \mathrm{~K})\end{array}$ & $\begin{array}{c}\sim 25 \\
(340 \mathrm{~K})\end{array}$ & - & $\begin{array}{c}0.04 \\
(340 \mathrm{~K})\end{array}$ & $\begin{array}{l}\text { Highly flexible films, } \\
P F \text { decreased with } \\
\text { aging. }\end{array}$ & [98] \\
\hline P3HT: $\mathrm{FeCl}_{3}$ & $\begin{array}{l}\text { Polymer dispersed } \\
\text { in ortho-DCB and } \\
\text { sonicated before } \\
\text { spin cast. }\end{array}$ & - & $\begin{array}{c}\sim 29 \\
\text { Average }\end{array}$ & $\begin{array}{c}95 \pm 12 \\
\text { MAX }\end{array}$ & compromised & - & 42 to $81 \mathrm{wt} \%$ SWCNT. & [99] \\
\hline P3HT: $\mathrm{FeCl}_{3}$ & $\begin{array}{l}\text { Polymer dispersed } \\
\text { in ortho-DCB. }\end{array}$ & - & $\begin{array}{c}\sim 29 \\
\text { Average }\end{array}$ & $\begin{array}{l}25 \pm 6 \\
\text { MAX }\end{array}$ & $\sim 0.13 \pm 0.03$ & $>0.01$ & $\begin{array}{c}8 \mathrm{wt} \% \\
\text { SWCNT, sonicated } \\
\text { before spin cast. }\end{array}$ & [99] \\
\hline PEDOT & $\begin{array}{l}\text { Potentiostatically } \\
\text { grown from } \\
\text { EDOT, thick free } \\
\text { standing films. }\end{array}$ & $\begin{array}{c}0.2- \\
13.0 \\
\text { In-situ } \\
\text { (MAX) }\end{array}$ & - & - & - & - & $\begin{array}{c}3.3-22.5 \mu \mathrm{m} \text { thick } \\
\text { redox. }\end{array}$ & [127] \\
\hline $\begin{array}{c}\text { PEDOT:PSS } \\
\text { DMSO }\end{array}$ & $\begin{array}{c}\text { PEDOT/PSS } \\
1: 1.6\end{array}$ & $\begin{array}{l}0.8 \pm 0.1 \\
\quad(\mathrm{RT})\end{array}$ & $\begin{array}{l}\sim 12 \\
(\mathrm{RT})\end{array}$ & - & - & - & $\begin{array}{l}\text { Undoped values, DC } \\
\text { conductivity, free } \\
\text { standing film } \\
10-30 \mu \mathrm{m} .\end{array}$ & [104] \\
\hline
\end{tabular}




\begin{tabular}{|c|c|c|c|c|c|c|c|c|}
\hline Material & $\begin{array}{c}\text { Production } \\
\text { process }\end{array}$ & $\begin{array}{c}\sigma \\
\left(\mathrm{S} \mathrm{cm}^{-1}\right)\end{array}$ & $\begin{array}{c}\alpha \\
\left(\mu \vee K^{-1}\right)\end{array}$ & $\begin{array}{c}\alpha^{2} \sigma \\
\left(\mu W \mathbf{m}^{-1} \mathbf{K}^{-2}\right)\end{array}$ & $\begin{array}{c}\kappa \\
\left(\mathbf{W} \mathbf{m}^{-1} \mathbf{K}^{-1}\right)\end{array}$ & $\mathbf{Z T}$ & Comments & Ref \\
\hline PEDOT:PSS & $\begin{array}{c}\text { Chemical } \\
\text { polymerization }\end{array}$ & 0.03 & - & - & - & - & Thin oxidized films. & [128] \\
\hline PEDOT:PSS & $\begin{array}{l}\text { Electrochemical } \\
\text { polymerization. }\end{array}$ & 80 & - & - & - & - & Thin oxidized films. & [128] \\
\hline PEDOT:Tos & $\begin{array}{l}\text { Electrochemical } \\
\text { polymerization. }\end{array}$ & 450 & - & - & - & - & $\begin{array}{l}\text { Unit cell composed of } \\
1 \text { tosylate anion for } \\
\text { every } 4 \text { EDOT. }\end{array}$ & [128] \\
\hline $\begin{array}{l}\text { PEDOT:Tos } \\
\text { Pyridine }\end{array}$ & $\begin{array}{c}\text { Vapour-phase } \\
\text { polymerization. }\end{array}$ & 1000 & - & - & - & - & $\begin{array}{l}\text { Base inhibiting acid- } \\
\text { initiated } \\
\text { polymerization of } \\
\text { EDOT. }\end{array}$ & [103] \\
\hline $\begin{array}{c}\text { PEDOT:PSS } \\
\text { DMSO }\end{array}$ & $\begin{array}{c}\text { PEDOT/PSS - } \\
1: 2.5 \\
\text { Polymer/DMSO - } \\
\text { 1:0.05 Spin coated. }\end{array}$ & 298.52 & 12.65 & 4.78 & - & - & $\begin{array}{c}\text { Possible reorientation } \\
\text { of PEDOT/PSS chains } \\
\text { caused by DMSO } \\
\text { leading to increased } \sigma .\end{array}$ & [109] \\
\hline PEDOT:PSS & $\begin{array}{c}\text { PEDOT/PSS - } \\
1: 2.5\end{array}$ & 0.06 & 888.18 & 4.42 & - & - & No DMSO & [109] \\
\hline $\begin{array}{l}\text { PEDOT:PSS } \\
\text { DMSO or EG }\end{array}$ & $\begin{array}{c}10 \% \text { DMSO } \\
\text { Free standing film. }\end{array}$ & $\begin{array}{l}298 \\
(\mathrm{RT})\end{array}$ & $\begin{array}{l}14.2 \\
(\mathrm{RT})\end{array}$ & - & - & 0.01 & $\begin{array}{c}\text { Cast on polypropylene } \\
\text { substrate }- \text { contact } \\
\text { angle } 87^{\circ} .\end{array}$ & [110] \\
\hline $\begin{array}{l}\text { PEDOT:PSS } \\
\text { DMSO or EG }\end{array}$ & $\begin{array}{l}10 \% \text { DMSO } \\
\text { pellets. }\end{array}$ & $\begin{array}{c}31 \\
(\mathrm{RT})\end{array}$ & - & - & - & 0.001 & $\begin{array}{c}\text { Free standing cast on } \\
\text { polypropylene } \\
\text { substrate }- \text { contact } \\
\text { angle } 87^{\circ} \text {. }\end{array}$ & [110] \\
\hline $\begin{array}{c}\text { PEDOT:PSS/ } \\
\mathrm{Ca}_{3} \mathrm{Co}_{4} \mathrm{O}_{9}(10: 1)\end{array}$ & $\begin{array}{c}\text { Mechanical } \\
\text { blending and } \\
\text { casting method. }\end{array}$ & $\begin{aligned} & 135 \\
& (\mathrm{RT}) \\
< & \text { pristine }\end{aligned}$ & $\begin{array}{c}16.7 \\
(\mathrm{RT}) \\
>\text { pristine }\end{array}$ & $\begin{aligned} & \sim 3.8 \\
& (\mathrm{RT}) \\
< & \text { pristine }\end{aligned}$ & - & - & $\begin{array}{l}\text { Particles in the shape } \\
\text { of sheets and } \\
\text { composited well } \\
\text { together. }\end{array}$ & [119] \\
\hline PEDOT:PSS/ Te & $\begin{array}{l}\text { Solution } \\
\text { processed. }\end{array}$ & $\begin{array}{c}19.3 \pm 2.3 \\
(\mathrm{RT})\end{array}$ & $\begin{array}{c}163 \pm 4 \\
(\mathrm{RT})\end{array}$ & $\begin{array}{l}70.9 \\
(\mathrm{RT})\end{array}$ & $\begin{array}{c}0.22-0.30 \\
(\mathrm{RT})\end{array}$ & $\begin{array}{c}0.1 \\
\text { MAX } \\
(\mathrm{RT})\end{array}$ & $\begin{array}{l}\text { Tellurium core } \\
\text { functionalized with } \\
\text { PEDOT/PSS. }\end{array}$ & [120] \\
\hline $\begin{array}{c}\text { PEDOT } \\
\text { nanowires }\end{array}$ & $\begin{array}{c}\text { Lithographically } \\
\text { patterned. }\end{array}$ & - & $\begin{array}{c}-122 \\
(310 \mathrm{~K})\end{array}$ & - & - & - & $\begin{array}{l}\text { Greater than films } \\
\qquad(\alpha=-57) .\end{array}$ & [112] \\
\hline PEDOT:PSS/ AF & $\begin{array}{l}\text { Thermally } \\
\text { decomposable } \\
\text { ammonium } \\
\text { formate }\end{array}$ & 0.036 & 436.3 & 0.69 & 0.18 & $\begin{array}{c}0.0011 \\
(\mathrm{RT})\end{array}$ & $\begin{array}{c}10 \% \mathrm{AF} \sim 40 x \text { larger } \\
\text { than films. }\end{array}$ & [111] \\
\hline PEDOT:Tos & $\begin{array}{c}\text { Chemical } \\
\text { polymerization } \\
\text { with iron tosylate. }\end{array}$ & $\begin{array}{c}\sim 80 \\
22 \% \text { Tos }\end{array}$ & $\begin{array}{c}\sim 220 \\
22 \% \text { Tos }\end{array}$ & $\begin{array}{c}324 \\
22 \% \text { Tos }\end{array}$ & $\begin{array}{c}0.37 \\
22 \% \text { Tos }\end{array}$ & $\begin{array}{l}0.25 \\
22 \% \\
\text { Tos }\end{array}$ & $\begin{array}{c}\text { Dedoping with } \\
\text { tetrakis(dimethylamino } \\
\text { )ethylene. }\end{array}$ & [69] \\
\hline PEDOT:PSS & $\begin{array}{l}\text { 5\% DMSO or EG } \\
\text { then immersed in } \\
\text { EG for dedoping } \\
\text { spin coated. }\end{array}$ & $\begin{array}{c}\sim 880 \\
(297 \mathrm{~K})\end{array}$ & $\begin{array}{c}\sim 72 \\
(297 \mathrm{~K})\end{array}$ & $\begin{array}{c}469 \\
(297 \mathrm{~K})\end{array}$ & $\begin{array}{c}0.42 \pm 0.07 \\
(/ /) \\
(297 \mathrm{~K})\end{array}$ & $\begin{array}{c}0.42 \\
(297 \mathrm{~K})\end{array}$ & $\begin{array}{c}\kappa \text { anisotropy }=1.4 \pm \\
0.22 \text { with DMSO } \\
\text { mixed }+ \text { EG treatment. } \\
\text { Results } \sim 120 \text { min. } \\
\text { dedoping. }\end{array}$ & [70] \\
\hline PP-PEDOT:Tos & $\begin{array}{l}\text { Solution Casting } \\
\text { Polymerization - } \\
\text { Fe(Tos) + EDOT, } \\
\text { pyridine and } \\
\text { triblock copolymer } \\
\text { PEPG. }\end{array}$ & $\sim 900$ & $\sim 120$ & $\begin{array}{c}1,270 \\
\text { Best results } \\
\text { to date }\end{array}$ & $\begin{array}{c}0.37 \\
\text { form ref. } 92\end{array}$ & 1.02 & $\begin{array}{c}\text { Finely tuned oxidation } \\
\text { level of polymer } \\
\text { electrochemically. }\end{array}$ & [71] \\
\hline PEDOT/PbTe & $\begin{array}{c}\text { Interfacial } \\
\text { polymerization of } \\
\text { PEDOT } / \mathrm{PbTe} \\
\text { modified. }\end{array}$ & $\sim 0.32$ & $\begin{array}{c}\sim \\
-2200\end{array}$ & 1.44 & - & - & $\begin{array}{c}n \text {-type, high } \alpha \text { up to } \\
4,088, \text { low } \sigma \text { of } 0.064 \\
\text { for pristine PEDOT. } \\
\text { Best results at } 28.7 \% \\
\text { PbTe }\end{array}$ & [116] \\
\hline
\end{tabular}




\begin{tabular}{|c|c|c|c|c|c|c|c|c|}
\hline Material & $\begin{array}{c}\text { Production } \\
\text { process }\end{array}$ & $\begin{array}{c}\sigma \\
\left(S \mathrm{~cm}^{-1}\right)\end{array}$ & $\begin{array}{c}\alpha \\
\left(\mu \vee K^{-1}\right)\end{array}$ & $\begin{array}{c}\alpha^{2} \sigma \\
\left(\mu \mathbf{W ~ m}^{-1} \mathbf{K}^{-2}\right)\end{array}$ & $\begin{array}{c}\kappa \\
\left(\mathbf{W} \mathbf{m}^{-1} \mathbf{K}^{-1}\right)\end{array}$ & $\mathbf{Z T}$ & Comments & Ref \\
\hline PEDOT/SWCNT & $\begin{array}{l}\text { Water dispersion } \\
\text { with sonication - } \\
\text { thick free standing } \\
\text { films by filtration. }\end{array}$ & - & - & $\sim 28$ & 0.444 & $\begin{array}{l}0.03 \\
(\mathrm{RT})\end{array}$ & $\begin{array}{c}40 \mathrm{wt} \% \text { SWCNT dried } \\
\text { at } 333 \mathrm{~K} \text { for } 24 \mathrm{~h} \text { under } \\
\text { vacuum. }\end{array}$ & 8 \\
\hline $\begin{array}{c}\text { PEDOT:PSS/ } \\
\text { GNP }\end{array}$ & $\begin{array}{l}\text { Water dispersion } \\
\text { with sonication, } \\
\text { spin coated film on } \\
\mathrm{SiO}_{2} \text { substrate. }\end{array}$ & 32.13 & 58.77 & 11.09 & 0.14 & 0.021 & $\begin{array}{l}2 \mathrm{wt} \% \text { GNP dried at } \\
353 \mathrm{~K} \text { for } 12 \text { hours. }\end{array}$ & [55] \\
\hline PEDOT/AuMH 2 & $\begin{array}{l}\text { Drop cast, glass } \\
\text { substrate, } 10-20 \\
\mu \mathrm{m} \text { thick film. }\end{array}$ & $\begin{array}{c}730 \\
(393 \mathrm{~K})\end{array}$ & $\begin{array}{c}26.5 \\
(393 \mathrm{~K})\end{array}$ & $\begin{array}{c}51.2 \\
(393 \mathrm{~K})\end{array}$ & $\begin{array}{c}0.2 \\
(393 \mathrm{~K})\end{array}$ & $\begin{array}{c}0.098 \\
(393 \mathrm{~K})\end{array}$ & $\begin{array}{l}0.01 \mathrm{mg} / \mathrm{ml} \text { solution, } \\
\text { dried in air for } 3 \mathrm{~h} \text { then } \\
\text { heated to } 373 \mathrm{~K} \text { under } \\
\text { vacuum for } 20 \mathrm{~min} .\end{array}$ & [122] \\
\hline $\begin{array}{c}\text { PEDOT:PSS } \\
\text { ionic liquids }\end{array}$ & $\begin{array}{c}\text { Drop cast solution, } \\
\text { Polypropylene } \\
\text { substrate. }\end{array}$ & $\begin{array}{l}\sim 125 \\
(\mathrm{RT})\end{array}$ & $\begin{array}{l}\sim 27 \\
(\mathrm{RT})\end{array}$ & $\begin{array}{c}9.9 \\
(\mathrm{RT})\end{array}$ & - & $\begin{array}{l}0.017 \\
(\mathrm{RT})\end{array}$ & $\begin{array}{l}\text { Dried under vacuum at } \\
353 \mathrm{~K} \text { for } 6 \mathrm{~h} \text { then } \\
\text { heated to } 373 \mathrm{~K} \text { under } \\
\text { vacuum for } 30 \mathrm{~min} \text {. }\end{array}$ & [123] \\
\hline PEDOT:PSS & $\begin{array}{c}\text { Inkjet printing } \\
\text { patterned polymer. }\end{array}$ & - & - & - & 0.17 & 0.041 & $14.5 \%$ oxidation level. & [129] \\
\hline $\begin{array}{c}\text { PEDOT:PSS } \\
\text { Te + 5\% DMSO }\end{array}$ & $\begin{array}{c}\text { Polymer dissolved } \\
\text { in acid followed } \\
\text { by addition of } \\
\mathrm{Na}_{2} \mathrm{TeO}_{3} \text {, cast } \\
\text { film. }\end{array}$ & - & - & $\begin{array}{c}100 \\
\text { MAX }\end{array}$ & - & - & $\begin{array}{l}\sim 2.5 \mu \mathrm{m} \text { thin films of } \\
\text { Te nanowire coated in } \\
\text { PEDOT:PSS. }\end{array}$ & [124] \\
\hline $\begin{array}{c}\text { PEDOT:PSS } \\
\mathrm{Bi}_{2} \mathrm{Te}_{3}\end{array}$ & $\begin{array}{c}\text { Drop cast, glass } \\
\text { substrate, and free } \\
\text { standing film } 10 \text { to } \\
15 \mu \mathrm{m} \text { thick. }\end{array}$ & 421 & $\sim 15$ & $\begin{array}{c}9.9 \\
\text { MAX }\end{array}$ & $0.07 \pm 0.02$ & 0.04 & $\begin{array}{c}\text { 1:2.5 PEDOT:PSS, } \\
10 \% \mathrm{Bi}_{2} \mathrm{Te}_{3}\end{array}$ & [125] \\
\hline $\begin{array}{c}\text { PEDOT:PSS } \\
50 \text { vol\% } \\
\text { EMIMBF }_{4}\end{array}$ & $\begin{array}{l}\text { Solution mixture } \\
\text { spin coated in } \\
\text { glass and silicone } \\
\text { substrate with } \\
\text { EMIMBF }_{4}\end{array}$ & - & - & - & 0.17 & $\begin{array}{c}0.068 \\
(\mathrm{RT})\end{array}$ & $\begin{array}{l}\text { Dropped on the pristine } \\
\text { film. Dried on hot plate } \\
\text { at } 403 \mathrm{~K} \text { for } 10 \mathrm{~min} \text {. in } \\
\text { ambient atmosphere. }\end{array}$ & [130] \\
\hline
\end{tabular}

\section{Acknowledgments}

We are grateful to the EPSRC Doctoral Training Centre in Plastic Electronics (grant number EP/G037515/1) for funding. 


\section{5- REFERENCES:}

[1]

C. Godart, A.P. Gonçalves, E.B Lopes, B. Villeroy, in Properties and Applications of Thermoelectric Materials, (Eds: V. Zlatic A. C. Hewson), Springer, Dordrecht, 2008 pp. 19-49.

J. C. Peltier, Ann. Chim 1834, 1, 371.

W. Thompson, Proc. R. Soc. Edinburgh 1851, 5, 91-97.

Nature 1879, 20, 301-302.

K.M. Saqr, M.N. Musa, Therm. Sci. 2009, 13, 165-174.

M.V. Vedernikov, E.K. Iordanishvili, in Proceedings of the 17thInternational Conference on Thermoelectrics, Nagoya, Japan, May 24-28, 1998, pp. 37-42.

A.F. Ioffe, Semiconductor Thermoelements and Thermoelectric Cooling, Infosearch Limited, London, 1957.

L. E. Bell, Science 2008, 321, 1457-1461.

X. W. Wang, H. Lee, Y. C. Lan, G. H. Zhu, G. Joshi, D. Z. Wang, J. Yang, A. J. Muto, M. Y. Tang, J. Klatsky, S. Song, M.S. Dresselhaus. G. Chen, Z.F. Ren., Appl. Phys. Lett. 2008, 93, 193121.

G. Joshi, H. Lee, Y. Lan, X. Wang, G. Zhu, D. Wang, R. W. Gould, D. C. Cuff, M. Y. Tang, M. S. Dresselhaus, G. Chen, Z. Ren, Nano Lett. 2008, 8, 4670-4674.

G. Fradkin, V. Kodyukov, At. Energy 1969, 26, 193-198.

W. J. F. Standring, M. Dowdall, M. Sneve, Ø. G. Selnaes, I. Amundsen, J. Radiol. Prot. 2007, 27, 321-331.

G. L. Bennett, Energy Convers. Manage. 2008, 49, 382-392.

N. Mathers, A. Goktogen, J. Rankin, M. Anderson, Acta Astronaut. 2012, 80, 124-131.

NASA, "Billion-Pixel View From Curiosity at Rocknest, Raw Color,"as accessed on the website: http://www.nasa.gov/mission_pages/msl/multimedia/pia16919.html, 2013.

L D.. Hicks, M. S. Dresselhaus, Phys. Rev. B 1993, 47, 12727-12731.

L D. Hicks, M. S. Dresselhaus, Phys. Rev. B 1996, 53, R10493.

L D. Hicks, T. C. Harman, X. Sun, M. S. Dresselhaus, Phys. Rev. B. 1996, 53, R10493..

D. Vashaee, A. Shakouri, Phys. Rev. Lett. 2004, 92, 106103. 
[31] M. Martín-González, O. Caballero-Calero, P. Díaz-Chao, Renewable Sustainable Energy Rev. 2013, 24, $288-305$.

[32] G. J. Snyder, E. S. Toberer, Nat. Mater. 2008, 7, 105-114.

[33] X. Shi, J. Yang, J. R. Salvador, M. Chi, J. Y. Cho, H. Wang, S. Bai, J. Yang, W. Zhang, L. Chen, J. Am. Chem. Soc. 2011, 133, 7837-7846.

[34] K. P. Ong, D. J. Singh, P. Wu, Phys. Rev. B 2011, 83, 115110.

[35] C. Sevik, T. Çağın, J. Appl. Phys. 2011, 109, 123712.

[36] J. Tang, H.-T. Wang, D. H. Lee, M. Fardy, Z. Huo, T. P. Russell, P. Yang, Nano Lett. 2010, 10, 4279-4283.

[37] X. Zhang, K. T. Chau, C. C. Chan, J. Asian Electr. Veh. 2008, 6, 1119-1124.

[38] A. J. Simon, R. D. Belles, "Energy Flow," as accessed on the website: https://flowcharts.llnl.gov/, 2011.

[39] Marlow Inc., "Transmission Lasers (DWDM)," as accessed on the website: http://www.marlow.com/industries/telecommunications/transmission-lasers-dwdm.html.

[40] Gentherm, “Climate Seats,” as accessed on the website: http://www.gentherm.com/page/climate-seats, 2014.

[41] "Power Practical," as accessed on the website: http://www.thepowerpot.com.

[42] U. Rass, Mobile Hearing Aid/ear Aligner, Has Thermoelectric Transducer with Rectangular Cross Section, Where Hot and Cold Poles of Transducer Contact Respective Inner and Outer Sides of Cover of Sound Hose for Power Supply of Aid, 2005.

[43] M. Kawata, A. Takakura, Thermoelectrically-Powered Wrist Watch, Patent EP0 837377 A1, 1997,.

[44] "Koolatron," as accessed on the website: http://www.koolatron.com/.

[45] M. Zhang, L. Miao, Y. P. Kang, S. Tanemura, C. A. J. Fisher, G. Xu, C. X. Li, G. Z. Fan, Appl. Energy 2013, 109, 51-59.

[46] G. Chen, J. Appl. Phys. 2011, 109, 104908

[47] H. Bottner, J. Nurnus, A. Gavrikov, G. Kuhner, M. Jagler, C. Kunzel, D. Eberhard, G. Plescher, A. Schubert, K.-H. Schlerth, J. Microelectromechanical Syst. 2004, 13, 414-420.

[48] J. J. Urban, K. C. See, R. A. Segalman, N. E. Coates, S. K. Yee, Inorganic Nanostructure-Organic Polymer Heterostructures Useful for Thermoelectric Devices, Patent US 20130084464, 2013.

[49] X. Crispin, M. Berggren, H. Wang, Thermoelectric Device, Patent US 20130276851. 2013.

[50] R. Nishio R., Aoai T., N. Hayashi, "Thermoelectric Conversion Material and Thermoelectric Conversion Element, Patent WO2013047730, 2013. 
[52] J. Baxter, Z. Bian, G. Chen, D. Danielson, M. S. Dresselhaus, A. G. Fedorov, T. S. Fisher, C. W. Jones, E. Maginn, U. Kortshagen, A. Manthiram, A. Nozik, D. R. Rolison, T. Sands, L. Shi, D. Sholl, Y. Wu, Energy Environ. Sci. 2009, 2, 559-588.

[53] M. G. Kanatzidis, Chem. Mater. 2009 22, 648-665.

[54] J. R. Sootsman, D. Y. Chung, M. G. Kanatzidis, Angew. Chem, Int Ed. 2009, 48, 8616, 8639.

[55] G. H. Kim, D. H. Hwang, S. I. Woo, Phys. Chem. Chem. Phys. 2012, 14, 3530-3536.

[56] M. Zebarjadi, K. Esfarjani, M. S. Dresselhaus, Z. F. Ren, G. Chen, Energy Environ. Sci. 2012, 5, 5147-5192

[57] O. Bubnova, X. Crispin, Energy Environ. Sci. 2012, 5, 9345-9362.

[58] Thermoelectrics Handbook: Macro to Nano, (Ed.: D. M. Rowe), Taylor And Francis, Hoboken, 2005.

[59] H. Zhao, M. Pokheral, G. Zhu, S. Chen, K. Lukas, Q. Jie, C. Opeil, G. Chen, Z. Ren, Appl. Phys. Lett. $2011,99,163101$.

[60] F. DiSalvo, Science 1999, 285, 703-706

[61] H. Wang, W. Porter, H Bottner, J. Konig, L. Chen, S. Bai, T. Tritt, A. Mayolet, J. Senawiratne, C. Smith, F. Harris, P. Gilbert, J. Sharp, J. Lo, H. Kleinke, L. Kiss, J. Electron. Mater. 2013, 42, 654-664.

[62] H. Wang, W. Porter, H Bottner, J. Konig, L. Chen, S. Bai, T. Tritt, A. Mayolet, J. Senawiratne, C. Smith, F. Harris, P. Gilbert, J. Sharp. J. Lo, H. Kleinke, L. Kiss, J. Electron. Mater. 2013, 42, 1073-1084.

[63] H. J. Snaith, Energy Environ. Sci. 2012, 5, 6513-6520.

[64] G. P. Smestad, F. C. Krebs, C. M. Lampert, C. G. Granqvist, K. L. Chopra, X. Mathew, H. Takakura, Sol. Energy Mater. Sol. Cells 2008, 92, 371-373.

[66] N. Dubey, M. Leclerc, J. Polym. Sci. Part B Polym. Phys. 2011, 49, 467-475.

[67] H. Shirakawa, E. J. Louis, A. G. MacDiarmid, C. K. Chiang, A. J. Heeger, J Chem Soc., Chem. Commun. 1977, 578-580.

[68] Y. Park, C. Yoon, C. Lee, H. Shirakawa, Y. Suezaki, K. Akagi, Synth. Met. 1989, 28, D29- D34.

[69] O. Bubnova, Z. U. Khan, A. Malti, S. Braun, M. Fahlaman, M Berggren, X. Crispin, Nat. Mater. 2011, 10, $429-433$.

[70] G, -H Kim, L. Shao, K. Zhang, K. P. Pipe, Nat. Mater. 2013, 12, 719-723,

[71] T. Park, C. Park, B. Kim, H. Shin, E. Kim, Energy Environ. Sci. 2013, 6, 788-792.

[72] Y. Sun, P. Sheng, C. Di, F. Jiao, W. Xu, D. Qiu, D. Zhu, Adv. Mater. 2012, 24, 932-937.

[73] C. Müller, T. A. M. Ferenczi, M. Campoy-Quiles, J. M. Frost, D. D. C. Bradley, P. Smith, N. Stingelin-Stutzmann, J. Nelson, Adv. Mater. 2008, 20, 3510-3515.

[74] M. A Baklar, F. Koch, A. Kumar, E. B. Domingo, M. Campoy-Quiles, K. Feldman, L. Y. Yu, P. Wobkenberg, J. Ball, R. M. Wilson, I. McCulloch, T. Kreouzis, M. Heeney, T. Anthopoulos, P. Smith, N. Stingelin, Adv. Mater. 2010, 22, 3942-3947.

[75] R. Zuzok, A. B. Kaiser, W. Pukacki, S. Roth, J. Chem. Phys. 1991, 95, 1270-1275.

[76] D. Moses, A. Denenstein, Phys. Rev. B 1984, 30, 2090-2097. 
[78] N. T. Kemp, A. B. Kaiser, C. J. Liu, B. Chapman, O. Mercier, A. M. Carr, H. J. Trodahl, R. G. Buckley, A. C. Partridge, J. Y. Lee, C. Y. Kim, A. Bartl, L. Dunsch, W. T. Smith, J. S. Shapiro, J. Polym. Sci., Part B: Polym. Phys. 1999, 37, 953-960.

[79] R. Gangopadhyay, A. De, S. Das, J. Appl. Phys,. Sci,. 2000, 87, 2363-2371.

[80] N. T. Kemp, A. B. Kaiser, H. J. Trodahl, B. Chapman, R. G. Buckley, A. C. Partridge, P. J. S. Foot, J. Polym. Sci., Part B: Polym. Phys. 2006, 44, 1331-1338.

[81] W. P. Lee, Y. W. Park, Y. S. Choi, Synth. Met. 1997, 84, 841-842.

[82] D. S. Maddison, R. B. Roberts, J. Unsworth, R. July, Synth. Met. 1989, 33, 281-287.

[83] E. R. Holland, S. J. Pomfret, P. N. Adams, L. Abell, A. P. Monkman, Synth. Mets 1997, 84, 777-778.

[84] H. Anno, M. Hokazono, F. Akagi, M. Hojo, N. Toshima, J. Electron. Mater. 2012, 42, 1346-1351.

[85] N. Toshima, M. Kajita, in Proceedings of the Twenty-First International Conference on Thermoelectrics (ICT '02), Long Beach, CA, August 25-29, 2002, pp. 147-150.

[86] H. Yan, T. Ohta, N. Toshima, Macromol. Mater.Eng. 2001, 286, 139-142.

[87] L. Jun, Z. Lian-meng, H. Li, T. Xin-feng, J. Wuhan Univ. Technol. Mater.Sci. Ed. 2003, 18, 53-55.

[88] J. M. Ginder, A. F. Richter, A. G. MacDiarimid, A. J. Epstein, Solid State Commun. 1987, 63, 97-101.

[89] P. K. Kahol, K. K. Satheesh Kumar, S. Geetha, D. C. Trivedi, Synth. Met. 2003, 139, 191-200.

[90] N. Toshima, M. Imai, S. Ichikawa, J. Electron. Mater. 2010, 40, 898-902.

[91] J. Xiang, L. T. Drzal, Polymer 2012, 53, 4202-4210.

[92] R. Aïch, N. Blouin, A. Bouchard, M. Leclerc, Chem. Mater. 2009, 21, 751-757.

[93] I. Lévesque, X. Gao, D. D. Klug, J. S. Tse, C. I. Ratcliffe, M. Leclerc, React. Funct. Polym. 2005, 65, 23-36.

[94] Y. Hiroshige, M. Ookawa, N. Toshima, Synth. Met. 2006, 156, 1341-1347.

[95] Y. Hiroshige, M. Ookawa, N. Toshima, Synth. Met. 2007, 157, 467-474.

[96] R. McCullough, R. Lowe, J. Chem. Soc., Chem. Commun. 1992, 70-72.

[97] Y. Xuan, X. Liu, S. Desbief, P. Leclère, M. Fahlman, R. Lazzaroni, M. Berggren, J. Cornil, D. Emin, X. Crispin, Phys. Rev. B 2010, 82, 115454.

[98] Q. Zhang, Y. Sun, W. Xu, D. Zhu, Energy Environ. Sci. 2012, 5, 9639-9644.

[99] C. Bounioux, P. Díaz-Chao, M. Campoy-Quiles, M. S. Martín-González, A. R. Goñi, R. Yerushalmi-Rozen, C. Müller, Energy Environ. Sci. 2013, 6, 918-925.

[100] B.-Y. Lu, C.-C. Liu, S. Lu, J.-K. Xu, F.-X. Jiang, Y.-Z. Li, Z. Zhang, Chin. Phys. Lett. 2010, 27, 1-4.

[101] E. Pinter, Z. A. Fekete, O. Berkesi, P. Makra, A. Patzko, C. Visy, J. Phys. Chem. C 2007, 111, 11872-11878. 
[102] L. Groenendaal, F. Jonas, D. Freitag, H. Pielartzik, J. R. Reynolds, Adv. Mater. 2000, 12, 481-494.

[103] B. Winther-Jensen, K. West, Macromolecules 2004, 37, 4538-4543.

[104] J. Kim, J. Jung, D. Lee, J. Joo, Synth. Met. 2002, 126, 311-316.

[105] H. J. Snaith, H. Kenrick, M. Chiesa, R. H. Friend, Polymer 2005, 46, 2573-2578.

[106] U. Lang, E. Müller, N. Naujoks, J. Dual, Adv. Funct. Mater. 2009, 19, 1215-1220.

[107] P. K. Choudhury, D. Bagchi, C. S. S. Sangeeth, R. Menon, J. Mater. Chem. 2011, 21, 1607-1614.

[108] A. M. Nardes, M. Kemerink, R.A. J. Janssen, J. A. M Bastiaansen, N. M. M. Kiggen, B. M. W. Langeveld. A. J. J. M. van Breenem, M. M. de Kok, Adv. Mater. 2007, 19, 1196-1200.

[109] K.-C. Chang, M.-S Jeng, C.-C. Yang, Y.-W. Chou, S.-K. Wu, M. A. Thomas, Y.C. C.-H. Peng, J. Electron. Mater. 2007, 19, 1196-1200.

[110] C. Liu, B. Lu, J. Yan, J. Xu, R. Yue, Z. Zhu, S. Zhou, X. Hu, Z. Zhang, P. Chen, Synth. Met. 2010, 160, $2481-2485$.

[111] T. -C. Tsai, H.-C. Chang, C.-H. Chen, W. -T Whang, Org. Electron. 2011, 12, 2159-2164.

[112] D. K. Taggart, Y. Yang, S.-C. Kung, T. M. McIntire, R. M. Penner, Nano Lett. 2011, 11, 125-131

[113] B. Winther-Jensen, K. Fraser, C. Ong, M. Forsyth, D. R. MacFarlane, Adv.. Mater. 2010, 22, 1727-1730.

[114] D. Evans, M. Fabretto, M. Mueller, K. Zuber, R. Short, P. Murphy, J. Matter. Chem. 2012, 22, 14889-14895.

[115] M. Mueller, M. Fabretto, D. Evans, P. Hojati-Talemi, C. Gruber, P. Murphy, Polymer. 2012, 53, $2146-2151$.

[116] Y. Wang, K. Cai, X. Yao, ACS Appl. Mater. Interfaces 2011, 3, 1163-1166.

[117] D. Kim, Y. Kium, K. Choi, J. Grunlan, c. Yu, ACS Nano 2009, 4, 513-523.

[118] G. P. Moriarty, S. De, P. J. King, U. Khan, M. Via, J. A. King, J. N. Coleman, J. C. Grunlan, J. Polym. Sci. Part B Polym. Phys. 2013, 51, 119-123S.

[119] C. Liu, F. Jiang, M. Huang. B. Lu, R. Yue, J. Xu, J. Electron. Mater. 2010, 40, 948-952.

[120] K. C. See, J. P. Feser, C. E. Chen, A. Majumdar, J. J. Urban, R. A. Segalman, Nano Lett. 2010, 10, 4664-4667.

[121] N. Toshima, N. Jiravanichanun, H. Marutani, J. Electron. Mater., 2012, 41, 1735-1742.

[122] N. Toshima, N. Jiravanichanun, J. Electron. Mater. 2013, 42, 1882-1887.

[123] C. Liu, J. Xu, B. Lu, R. Yue, F. Kong, J. Electron. Mater. 2012, 41, 639-645.

[124] S. K. Yee, N. E. Coates, A. Majumdar, J. J. Urban, R. A. Segalman, Phys, Chem, Chem, Phys. 2013, 15, 4024-4032.

[125) H. Song. C. Liu, H. Zhu, F. Kong. B. Lu, J. Xu, J. Wang, F. Zhao, J. Electron. Mater. 2013, 42, $1268-1274$.

[126] E. S. Choi, Y. H. Seola, Y. S. Song, Y. W. Park, Synth. Met. 1997, 84, 747-748.

[127] M. C. Morvant, J. R. Reynolds, Synth. Met. 1998, 92, 57-61. 
[128] X. Crispin, S. Marciniak, w. Osikowicz, G. Zotti, A. W. D. van der Gon, F. Louwet, M. Fahlman, L. Groenendaal, F. De Schryver, W. R. Salaneck, J. Polym. Sci. 2003, 41, 2561-2583.

129] O. Bubnova, M. Berggren, X. Crispin, J. Am. Chem. Soc. 2012, 134, 16456-16459.

[130] J. Luo, D. Billep, T. Waechtler, T. Otto, M. Toader, O. Gordan, E. Sheremet, J. Martin, M. Hiedschol, D. R. T, Zahn, T. Gessner, J. Mater. Chem. A 2013, 1, 7576-7583. 